\title{
Apparent Alkyl Transfer and Phenazine Formation via an Aryne Intermediate
}

\author{
Daniel Becker \\ Loyola University Chicago, dbecke3@luc.edu
}

Andria M. Panagopoulos

Loyola University Chicago

Doug Steinman

Loyola University Chicago

Alexandra Goncharenko

Loyola University Chicago

Kyle Geary

Loyola University Chicago

Follow this and additional works at: https://ecommons.luc.edu/chemistry_facpubs

Part of the Chemistry Commons

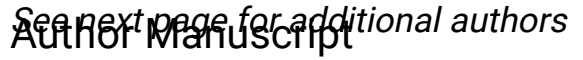

This is a pre-publication author manuscript of the final, published article.

\section{Recommended Citation}

Becker, Daniel; Panagopoulos, Andria M.; Steinman, Doug; Goncharenko, Alexandra; Geary, Kyle; Schleisman, Carlene; Spaargaren, Elizabeth; and Zeller, Matthias. Apparent Alkyl Transfer and Phenazine Formation via an Aryne Intermediate. Journal of Organic Chemistry, 78, 8: , 2013. Retrieved from Loyola eCommons, Chemistry: Faculty Publications and Other Works, http://dx.doi.org/10.1021/jo302795w

This Article is brought to you for free and open access by the Faculty Publications and Other Works by Department at Loyola eCommons. It has been accepted for inclusion in Chemistry: Faculty Publications and Other Works by an authorized administrator of Loyola eCommons. For more information, please contact ecommons@luc.edu. c) (i) $\Theta$

This work is licensed under a Creative Commons Attribution-Noncommercial-No Derivative Works 3.0 License. (C) 2013 American Chemical Society 


\section{Authors}

Daniel Becker, Andria M. Panagopoulos, Doug Steinman, Alexandra Goncharenko, Kyle Geary, Carlene Schleisman, Elizabeth Spaargaren, and Matthias Zeller 


\title{
Apparent Alkyl Transfer and Phenazine Formation via an Aryne Intermediate
}

Andria M. Panagopoulos, ${ }^{\S a}$ Doug Steinman, ${ }^{\S}$ Alexandra Goncharenko, ${ }^{\S}$ Kyle Geary, ${ }^{\S}$ Carlene Schleisman, ${ }^{\S}$ Elizabeth Spaargaren, ${ }^{\S}$ Matthias Zeller, ${ }^{\ddagger}$ and Daniel P. Becker ${ }^{\S} *$

${ }^{\S}$ Department of Chemistry, Loyola University Chicago, 1032 W. Sheridan Road, Chicago, IL 60660, United States, ${ }^{\ddagger}$ Department of Chemistry, 1 University Plaza, Youngstown State University, Youngstown, Ohio 44555-3663, United States

*dbecke3@luc.edu; ${ }^{a}$ Current Address: Oak Ridge National Laboratory, Chemical Sciences Division, Oak Ridge, TN 37831

\begin{abstract}
Treatment of chlorotriaryl derivatives 3a and 3d or fluorotriaryl
derivatives $\mathbf{3 b}$ and $\mathbf{3 e}$ with potassium diisopropylamide afforded alkyl-shifted phenazine derivatives $\mathbf{5 a} / \mathbf{5 b}$, rather than the expected 9-membered triaza orthocyclophane $\mathbf{2 a}$. The phenazine derivatives were isolated in $78-98 \%$ yield depending on the halogen and alkyl group present. In the absence of the halogen (chloro or fluoro), the apparent alkyl shift proceeds more slowly and cannot proceed via, the intermediacy of the aryne intermediate.. Mechanistic possibilities include intramolecular nucleophilic attack on an aryne intermediate leading to a zwitterionic intermediate and alkyl transfer via either a via a 5-endo-tet process, or via a Smiles rearrangement.
\end{abstract}

\section{INTRODUCTION}

Cyclotriveratrylene (CTV, 1), a [1.1.1]orthocyclophane, is an archetypal cyclophane scaffold that is commonly employed in supramolecular chemistry. ${ }^{1-4}$ As part of our research program directed toward the synthesis and application of apex-modified CTV derivatives ${ }^{5-7}$ with unique material properties and applications involving host-guest 
chemistry $^{8}$ we recently reported the synthesis of the new triaza orthocyclophane $\mathbf{2} \mathbf{a}^{9}$ (Figure 1) which was alkylated to give the N,N',N"-trimethyl derivative $\mathbf{2 b}$. Following a 6-step linear sequence to obtain the precursor 3a (Scheme 1), two mechanistically different approaches were examined in order to obtain the final desired triazacyclophane 2a (Scheme 1). The first method employed a Buchwald-Hartwig N-arylation, ${ }^{10-13}$ which was ultimately successful in the macrocyclization of $\mathbf{3 a}$ to azacyclophane $\mathbf{2 a}{ }^{9}$ In parallel, we had also envisioned that the use of benzyne (aryne) intermediate $4 \mathbf{a}$ should be a viable synthetic route to the triazacyclophane skeleton, which led to the observation of an unexpected alkyl transfer and phenazine formation with interesting mechanistic implications that we describe herein.
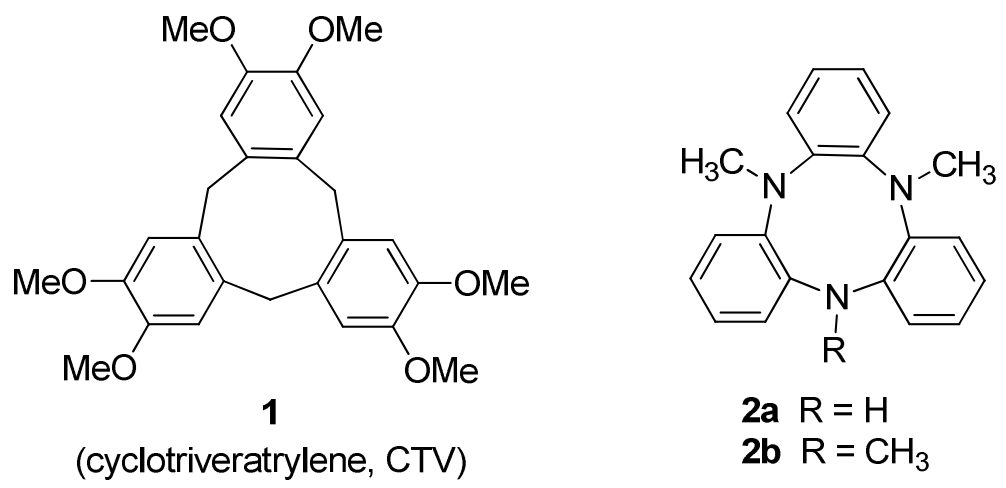

Figure 1: Structures of CTV and 1,4,7-triazacyclononatriene derivatives

Ring closures via aryne intermediates were first introduced independently by Bunnett ${ }^{14}$ and Huisgen. ${ }^{15}$ Since then, aryne intermediates have been used extensively in organic synthesis ${ }^{16}$ and in the synthesis of natural products. ${ }^{17}$ Barluenga et al. exploited the use of benzyne-tethered vinyl or aryl lithium compounds to obtain indole and benzo-fused 
heterocyclic derivatives. ${ }^{18}$ The reactivity of aryne intermediates toward nucleophilic attack is attributed to the low energy LUMO, which is a consequence of the "bending" of the triple bond within the ring; decreasing the energy gap between the LUMO of the aryne and the HOMO of the attacking nucleophile enables reaction between the two partners. ${ }^{19}$ For generating benzyne intermediates, a well-established method involves treating an aryl halide with a strong base, especially alkali metal aryls/alkyls or amides in ether solvents or liquid ammonia. Limitations arising from these reactions are due to the tendency for the solvent or the base itself to react with the benzyne intermediate, or from reduction of the benzyne via hydride transfer from the alpha-carbon of an amide base such as lithium diisopropylamide (LDA). ${ }^{19}$

\section{RESULTS AND DISCUSSION}

When we treated intermediate 3a with potassium diisopropylamide (KDA) in THF under reflux in order to form benzyne intermediate $\mathbf{4 a}$, a curious methyl shift was observed accompanied by the production of an unexpected phenazine derivative 5a, rather than the desired triaza orthocyclophane derivative 2a (Scheme 1). Reactions that were attempted with lithium diisopropylamide (LDA) were more sluggish and were not as clean. We had expected that the most nucleophilic anilide nitrogen $\left(\mathrm{N}^{3}\right)$ would react rather than the neutral, more sterically encumbered, and presumably less nucleophilic tertiary nitrogen $\left(\mathrm{N}^{2}\right)$. 


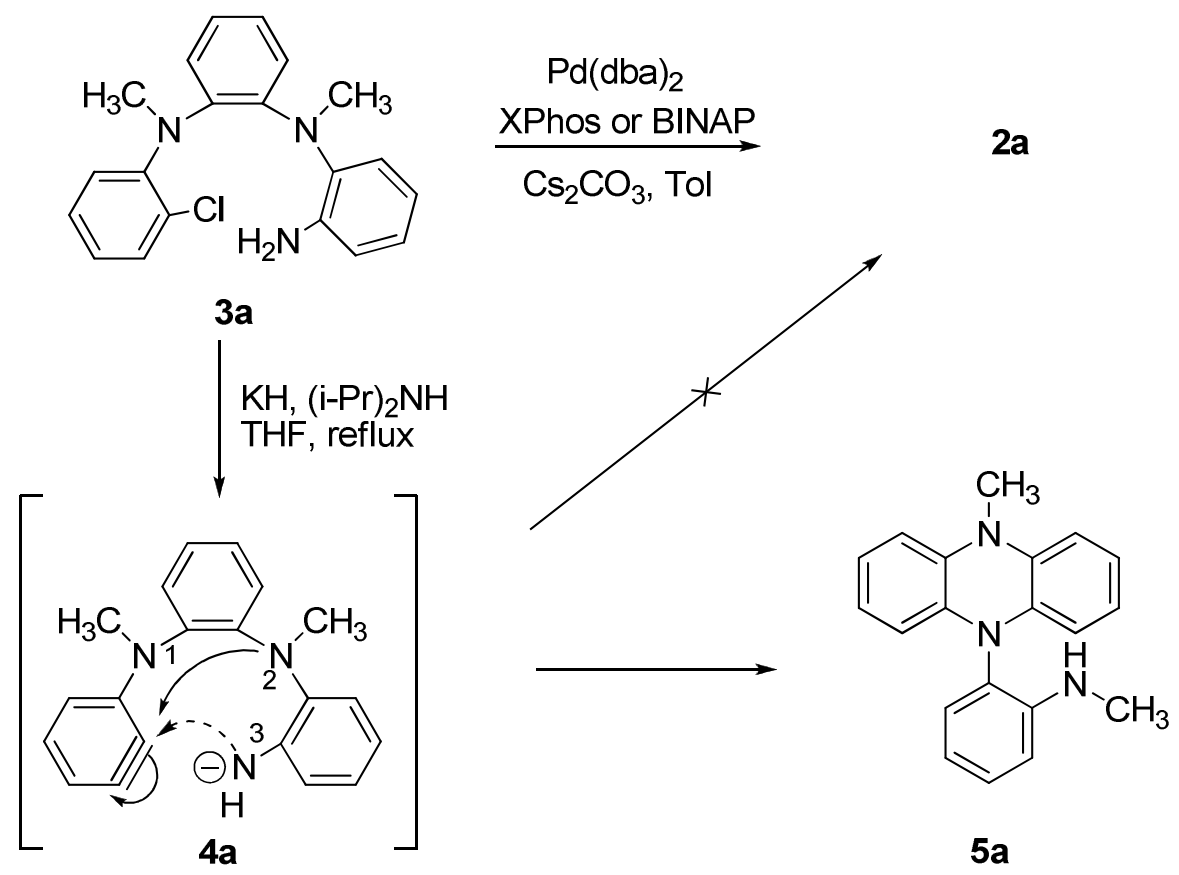

Scheme 1: Cyclization of 3a via Buchwald-Hartwig yielding orthocyclophane 2a and benzyne route affording phenazine $\mathbf{5 a}$

\begin{abstract}
Although the high-resolution molecular ion observed at 301.1562 was consistent with the expected molecular formula for orthocyclophane $\mathbf{2 a}$, the isomeric structure $\mathbf{5 a}$ was suggested by analysis of the spectral data and was ultimately confirmed by single crystal X-ray analysis of its tosylate and hydrochloride salts (Figures 2 and S1). Both salts independently afforded X-ray quality crystals from diethyl ether.
\end{abstract}




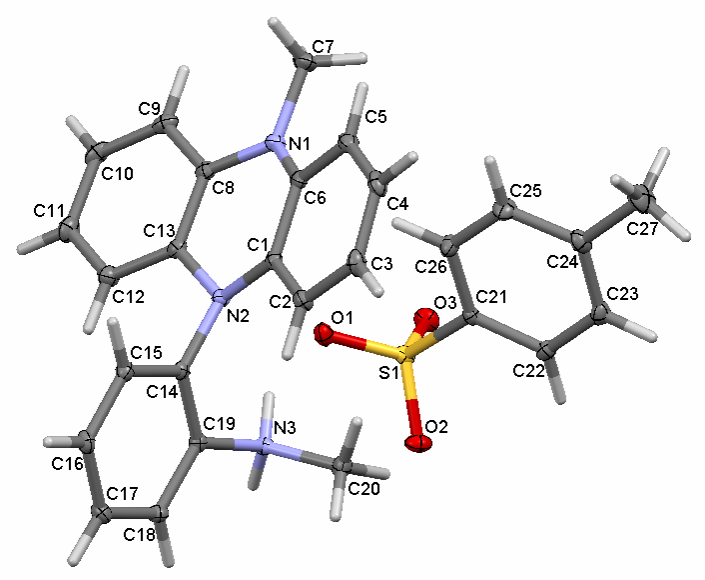

Figure 2: X-Ray crystal structure of the methyl-shifted phenazine 5a as the tosylate salt. Thermal ellipsoid probability level at 50\%.

The phenazine by-product was surprising since molecular models had predicted an ideal overlap of the $\mathrm{N}^{3}$ anionic anilide lone pair with the in-plane orbital on the proximal alkyne carbon of the benzyne, and we conjectured that the entropic cost of forming the 9membered ring would not be prohibitive due to the conformational constraints provided by the three intervening aryl rings. Yet 6-membered ring formation with alkyl shift proceeds exceptionally efficiently, with only the phenazine derivative as the major product formed and isolated (92\% yield).

We assumed that intramolecular or intermolecular methyl transfer from $\mathrm{N}^{2}$ to $\mathrm{N}^{3}$ was faster than the closure of the 9-membered ring, and might be faster than formation of the benzyne. Thus, we sought to slow down the alkyl transfer. Since $S_{N} 2$ displacement of a primary center is $\sim 50 \times$ slower than of a methyl center, ${ }^{20}$ we replaced the $\mathrm{N}^{2}$-methyl by an $n$-butyl group. Scheme 2 describes the preparation of the requisite $n$-butyl derivative 
3d wherein $\mathrm{X}=\mathrm{Cl}$. Adapted from our earlier report ${ }^{5}$, intermediate 9a was alkylated with n-butyl bromide to afford N-methyl-N'-butyl derivative 10d, which was reduced according to the general method of Sanz ${ }^{21}$ to afford 3d. Ultimately, we also wanted to speed up the formation of the aryne intermediate by utilizing the fluoride substrates $(\mathbf{3 b}$ and 3e), which commenced via a Buchwald-Hartwig reaction on 2-fluoro-iodobenzene $(\mathrm{X}=\mathrm{F}, \mathrm{Y}=\mathrm{I})$ to give the diarylamine $\mathbf{6 b}$ after purification by column chromatography. Methylation of $\mathrm{N}^{1}$ was accomplished with $\mathrm{KOH}$ and $\mathrm{Me}_{2} \mathrm{SO}_{4}$ in refluxing acetone ${ }^{22}$ or with sodium hydride followed by methyl iodide to give 2-fluoro-2'-nitrodiphenylamine 7b. This was followed by reduction of the nitro group to give aniline $\mathbf{8 b}$ employing the general method of $\mathrm{Sanz}^{21}$ using $\mathrm{CuCl}$ and $\mathrm{KBH}_{4}$ in dry $\mathrm{MeOH}$. Pd-catalyzed N-arylation of $\mathbf{8 b}$ with o-iodonitrobenzene produced the triaryl derivative $\mathbf{9 b}$ in $55 \%$ isolated yield after purification. Methylation of $\mathrm{N}^{2}$ proceeded with $\mathrm{KH}$ and $\mathrm{MeI}$ in warm DMF, and reduction of the nitro group was once again accomplished using $\mathrm{CuCl}$ and $\mathrm{KBH}_{4}$ to give compounds $\mathbf{1 0 b}$ and $\mathbf{3 b}$ respectively. Finally, nor-halo substrates $\mathbf{3 c}$ and $\mathbf{3 f}(\mathrm{X}=\mathrm{H} ; \mathrm{R}=$ $\mathrm{CH}_{3}$ or $n$-butyl, respectively) were prepared by Buchwald-Hartwig N-arylation of 2nitroaniline with bromobenzene to afford $\mathbf{6} \mathbf{c}^{23}$ which was alkylated to give $7 \mathbf{c}^{24}$ Reduction of nitroaniline $\mathbf{7 c}$ gave $\mathbf{8 c}$, which underwent $\mathrm{N}$-arylation to afford phenylene diamine derivative 9c. Alkylation with either methyl iodide or n-bromobutane gave 10c and 10f, respectively, followed by reduction to give $\mathbf{3 c}$ and $\mathbf{3 f}$, respectively. 

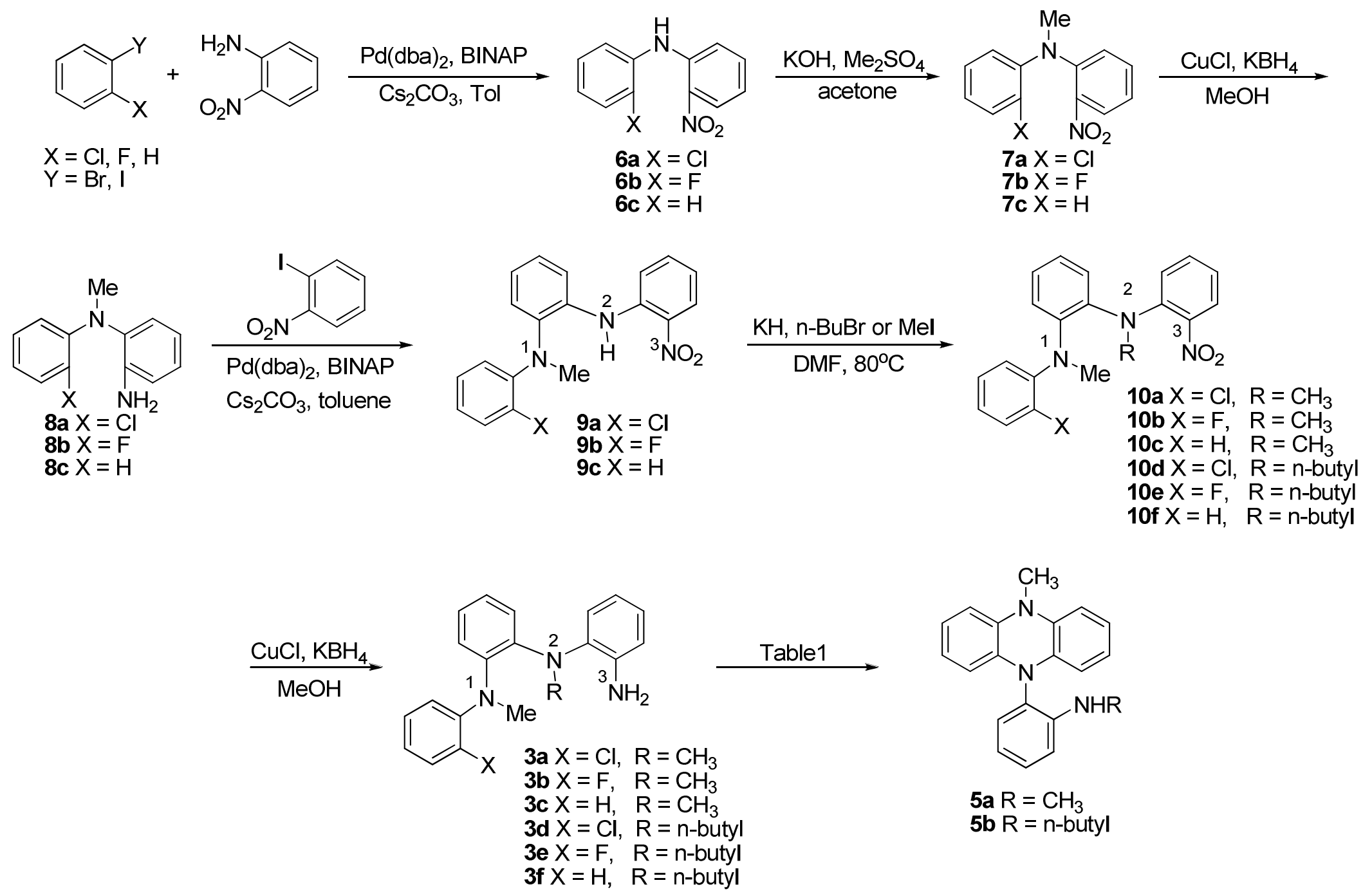

Table1

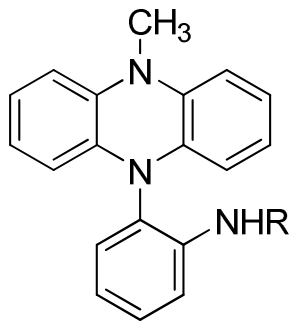

$5 \mathbf{a}=\mathrm{CH}_{3}$

5b R $=$ n-butyl

Scheme 2: Synthesis of triaryl derivatives 3a-f and formation of alkyl-shifted phenazine derivatives $\mathbf{5 a}$ and $\mathbf{5 b}$. 
As noted above, treatment of starting material 3a with KDA in THF under reflux afforded phenazine derivative 5a which had suffered the apparent methyl shift. Table 1 outlines the different reaction conditions and substrates explored. The order in which the alkyl shift is occurring appears to be dependent upon several factors including the halogen leaving group as well as the alkyl group substituent on the internal nitrogen $\left(\mathrm{N}^{2}\right)$. When the reaction of chloro- $\mathrm{N}, \mathrm{N}^{\prime}$-dimethyl aniline $3 \mathbf{a}$ was carried out at $-78^{\circ} \mathrm{C}$ (entry 1 ) no reaction occurred, as confirmed by $96 \%$ recovery of 3a even though benzyne formation has been observed at this temperature in some cases. However, when the reaction mixture was heated to reflux $\left(66^{\circ} \mathrm{C}\right)$, phenazine $\mathbf{5 a}$ was isolated in $92 \%$ yield having suffered the apparent methyl shift (entry 2). In an attempt to slow the rate of the $\mathrm{S}_{\mathrm{N}} 2$ reaction, in consideration of the possibility that demethylation preceded the formation of the benzyne intermediate and that prior alkyl transfer from $\mathrm{N}^{2}$ to $\mathrm{N}^{3}$ was essential for phenazine formation, the incorporation of a more sterically hindered blocking group was employed. Initial attempts to install an isopropyl substituent led to elimination, though these efforts were not exhaustive, so an $n$-butyl group on the internal nitrogen $\left(\mathrm{N}^{2}\right)$ was employed since $\mathrm{S}_{\mathrm{N}} 2$ displacement of a primary center is $\sim 50 \times$ slower than of a methyl center. ${ }^{20}$ The reaction with the $\mathrm{N}^{2}$-butyl derivative $\mathbf{3 d}$ was conducted under the same conditions (KDA, THF, reflux, entry 4) and remarkably, no reaction occurred, including no alkyl shift, hence aryne formation must have preceded the alkyl shift and is required for the alkyl shift to occur for this particular substrate. Alternatively, this suggests the unexpected possibility that the benzyne formation itself may be 
dependent upon prior alkyl shift since the $\mathrm{N}, \mathrm{N}^{\prime}$-dimethyl derivative did afford the methylshifted phenazine under the same conditions (entry 2). When the reaction was conducted in a sealed vessel at $95^{\circ} \mathrm{C}$ (entry 5) alkyl transfer of the butyl group was seen with concomitant formation of the phenazine derivative $\mathbf{5 b}$. The higher temperature required for the butyl shift is consistent with the rate difference for primary alkyl versus methyl substrates in an $\mathrm{S}_{\mathrm{N}} 2$-type reaction.

Table 1: Phenazine formation via benzyne intermediates<smiles>[X]c1ccccc1N([R7])c1ccccc1N([R2])c1ccccc1N</smiles>

$\mathrm{KH}, \mathrm{i}-\mathrm{PrNH}$ THF<smiles>[R2]Nc1ccccc1N1c2ccccc2N([R])c2ccccc21</smiles>

\begin{tabular}{|c|c|c|c|c|c|c|}
\hline Entry & S.M. & $\mathbf{X}$ & $\mathbf{R}_{\mathbf{1}}$ & $\mathbf{R}_{\mathbf{2}}$ & Temp & Product \\
& & & & & & \\
\hline 1 & $\mathbf{3 a}$ & $\mathrm{Cl}$ & $\mathrm{CH}_{3}$ & $\mathrm{CH}_{3}$ & -78 & no reaction \\
\hline 2 & $\mathbf{3 a}$ & $\mathrm{Cl}$ & $\mathrm{CH}_{3}$ & $\mathrm{CH}_{3}$ & 66 & $\mathbf{5 a}$ \\
\hline 3 & $\mathbf{3 b}$ & $\mathrm{F}$ & $\mathrm{CH}_{3}$ & $\mathrm{CH}_{3}$ & 66 & $\mathbf{5 a}$ \\
\hline 4 & $\mathbf{3 d}$ & $\mathrm{Cl}$ & $\mathrm{CH}_{3}$ & $n$-butyl & 66 & no reaction \\
\hline 5 & $\mathbf{3 d}$ & $\mathrm{Cl}$ & $\mathrm{CH}_{3}$ & $n$-butyl & 95 & $\mathbf{5 b}$ \\
\hline 6 & $\mathbf{3 e}$ & $\mathrm{F}$ & $\mathrm{CH}_{3}$ & $n$-butyl & 66 & $\mathbf{5 b}$ \\
\hline
\end{tabular}


We considered that the rate of dealkylation in the case of $\mathrm{R}^{2}=\mathrm{CH}_{3}$ may be faster than the rate of the benzyne formation (Scheme 2). The deprotonated terminal aniline nitrogen $\left(\mathrm{N}^{3}\right.$, structure 11) should be more basic as well as more nucleophilic than the $\mathrm{N}^{2}$ dealkylated anilide 12. Therefore, if a dynamic equilibrium exists wherein the alkyl substituent can shuttle back and forth between $\mathrm{N}^{2}$ and $\mathrm{N}^{3}$ (anilides $\mathbf{1 1}$ and 12, Scheme 3), then the equilibrium should shift toward having the anionic charge on $\mathrm{N}^{2}$ where it enjoys greater stabilization via resonance. This, however, begs the question of why $\mathrm{N}^{1}$ is not dealkylated as well. The isolated phenazine always bears a methyl on $\mathrm{N}^{1}$ and is not observed as a mixture of $\mathrm{N}^{1}-\mathrm{CH}_{3}$ and $\mathrm{N}^{1}-\mathrm{H}$ derivatives. However, only $\mathrm{N}^{2}$ is appropriately spaced to attack the benzyne, and dealkylation of $\mathrm{N}^{1}$ would be very unlikely after the phenazine formation since the $N$-methyl bond is orthogonal to the $\pi$ system. The direct transfer of the methyl from $\mathrm{N}^{2}$ to $\mathrm{N}^{3}$ (11a to 12) requires an a priori forbidden ${ }^{25}$ but occasionally observed ${ }^{26} 5$-endo-tet mechanism. The transition state for the 5-endo-tet in this case, however, is essentially an $\mathrm{S}_{\mathrm{N}} 2$ reaction from the same face as the leaving group. Alternatively, a Smiles ${ }^{27}$ rearrangement (11b-d) may occur which would appear to proceed via an alkyl shift while actually exchanging $\mathrm{N}^{2}$ and $\mathrm{N}^{3}$ along with their respective substituents. The Smiles rearrangement often proceeds with anionstabilizing groups on the aromatic ring that is attacked, and typically with an exchange of heteroatoms, for example an $\mathrm{N}$-nucleophile replacing an O-leaving group. 


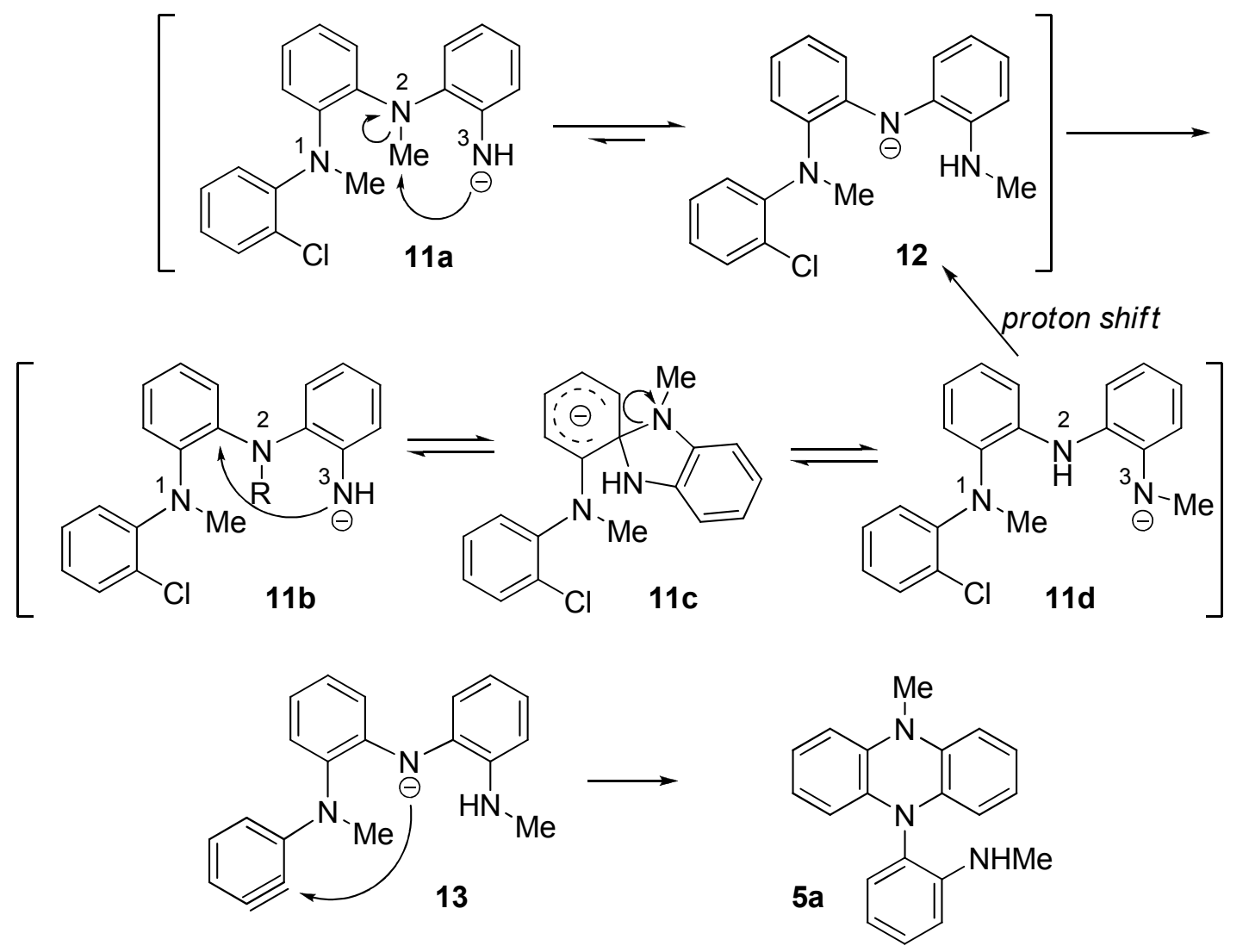

Scheme 3: Possible mechanism of alkyl shift prior to phenazine formation

Encouraged by the lack of alkyl shift with $\mathrm{R}^{2}=$ butyl in our quest for a benzyne approach to the 1,4,7-triazacyclononatriene, we reasoned that if the benzyne could be formed under milder conditions, then $\mathrm{N}^{2}$ would remain blocked and potentially circumvent 6membered ring formation. We therefore decided to change the halogen from chlorine to fluorine to enhance the rate of formation of the aryne as it can stabilize the incipient negative charge on the adjacent carbon. ${ }^{28,29}$ Substitution of the chlorine atom with a fluorine atom was accomplished as outlined in Scheme 2, adapted from our earlier 
reported procedure ${ }^{9}$ as described above. Treatment of fluoro aniline substrate $\mathbf{3 b}$ with KDA in refluxing THF afforded a 98\% yield of phenazine $\mathbf{5 a}$ (Table 1, entry 3).

The formation of phenazine derivative 5a employing fluorine as the halogen led us to combine strategies and introduce the $n$-butyl substituent on $\mathrm{N}^{2}$ as was done for substrate 3d. When aniline 3e containing the fluorine and the $n$-butyl group was subjected to KDA in refluxing THF (Table 1, entry 6), the alkyl transfer was once again observed giving rise to phenazine $\mathbf{5 b}$ in $98 \%$ isolated yield, and suggests that the formation of the benzyne intermediate precedes that of the alkyl transfer. The possible change in the reaction sequence and the isolation of phenazine $\mathbf{5 b}$ suggests the unusual zwitterion $\mathbf{1 4 a} \mathbf{a} / \mathbf{b}$ as an intermediary (Scheme 4). The zwitterion could be formed from the neutral, tertiary aniline attacking the benzyne intermediate, followed by either an intramolecular alkyl transfer again via a 5-endo-tet mechanism, or via intermolecular $\mathrm{S}_{\mathrm{N}} 2$ dealkylation. Formation of zwitterions $\mathbf{1 4 a} / \mathbf{b}$ requires attack by a less nucleophilic neutral aniline in the presence of a more nucleophilic anilide, yet the formation of a zwitterion from attack by a neutral nucleophile on an aryne is not without precedent. Kunai and co-workers ${ }^{30}$ reported nucleophilic attack on an aryne by an imidazole forming a zwitterion which was neutralized by abstraction of a proton, consistent with our proposed intermediates 14a and 14b. Since the internal nitrogen $\mathrm{N}^{2}$ has no proton to abstract, dealkylation is required to lead to the neutral phenazine derivative. We believe that the alkyl transfer is intramolecular, although labeling experiments would be required to confirm this in the present case. Reactant concentrations were kept intentionally rather low to encourage intramolecular macrocycle formation and to discourage intermolecular processes; the 
dimethyl chloro-aniline 3a concentration was $0.05 \mathrm{M}$ and the methyl butyl chloro-aniline 3d concentration was at $0.03 \mathrm{M}$, whereas KDA concentrations were kept at $0.17 \mathrm{M}$ and $0.16 \mathrm{M}$ in these two reactions respectively (initial concentrations of DIPA in the presence of excess $\mathrm{KH})$. Phenazines $\mathbf{5 a}$ and $\mathbf{5 b}$ were isolated in high yield in both cases, and we did not isolate any phenazine where the $\mathrm{N}^{2}$-alkyl group was lost rather than transferred, as would be expected if a slower intermolecular process were competing with dealkylation by KDA in solution. Alternatively, a Smiles rearrangement could precede or even follow aryne formation.

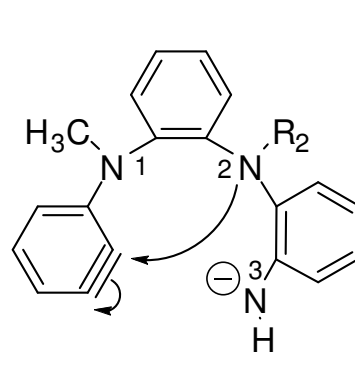

4a $\mathrm{R}_{2}=\mathrm{CH}_{3}$ 4b $\mathrm{R}_{2}=\mathrm{CH}_{2} \mathrm{CH}_{2} \mathrm{CH}_{2} \mathrm{CH}_{3}$

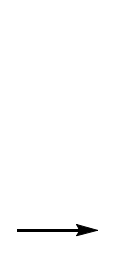<smiles>[R6]C1=[N+]2c3ccccc3N(C)c3ccccc3[N+]2(c2ccccc2N)c2ccccc21</smiles>

14a $\mathrm{R}_{2}=\mathrm{CH}_{3}$ 14b $\mathrm{R}_{2}=\mathrm{CH}_{2} \mathrm{CH}_{2} \mathrm{CH}_{2} \mathrm{CH}_{3}$<smiles>[R2]Nc1ccccc1N1c2ccccc2N(C)c2ccccc21</smiles>

5a $\mathrm{R}=\mathrm{CH}_{3}$ 5b $\mathrm{R}=\mathrm{CH}_{2} \mathrm{CH}_{2} \mathrm{CH}_{2} \mathrm{CH}_{3}$

Scheme 4: Alkyl shift and rearrangement via proposed zwitterionic intermediate 14

In order to determine if alkyl transfer is dependent on prior benzyne formation, substrates lacking a halogen leaving group were subjected to the identical conditions which were employed for benzyne formation. Nor-halo derivatives $\mathbf{3 c}$ and $\mathbf{3 f}$ were synthesized as outlined in Scheme 2 bearing methyl and $n$-butyl groups on $\mathrm{N}^{2}$, respectively. When compound $\mathbf{3 c}$ was treated with KDA in refluxing THF, one methyl substituent was cleanly transferred from $\mathrm{N}^{2}$ to the terminal $\left(\mathrm{N}^{3}\right)$ aniline nitrogen affording $15 \mathrm{c}$ in $89 \%$ 
yield (Scheme 5), demonstrating that dealkylation can occur independently of benzyne formation by the action of the nucleophilic terminal anilide $\left(\mathrm{N}^{3}\right)$. When anilide $3 \mathrm{f}$ bearing $\mathrm{N}^{1}$-methyl and $\mathrm{N}^{2}$-butyl groups but no halogen was subjected to KDA in THF at reflux, the major product isolated in $73 \%$ yield was the $\mathrm{N}^{3}$-butyl derivative $\mathbf{1 5 f}$, with the methyl group remaining on the $\mathrm{N}^{1}$ position. This result is surprising since the angle of attack by the $\mathrm{N}^{3}$-anilide nitrogen is not ideal for an $\mathrm{S}_{\mathrm{N}} 2$ reaction for the proximal $\mathrm{N}^{2}$-methyl (5endo-trig). This experiment employing aryl substrates lacking a halogen that are unable to form an aryne demonstrates that the alkyl shift can occur without benzyne formation. Furthermore, the $\mathrm{N}^{2}$-methyl or $\mathrm{N}^{2}-n$-butyl are the groups transferred, as evidenced by upfield ${ }^{13} \mathrm{C}$ shifts of the migrating carbon, and by comparison with calculated ${ }^{13} \mathrm{C}$ spectra utilizing $a b$ initio density functional (DFT) calculation of equilibrium geometry with RB3LYP/6-31G* level of theory (Supplementary Schemes S1 and S2).

We believe that the alkyl transfer from $\mathrm{N}^{2}$ to $\mathrm{N}^{3}$ in the conversion of $\mathbf{3 c / f}$ to $\mathbf{1 5} \mathbf{c} / \mathbf{f}$ is intramolecular. In the case of the nor-halo substrate $\mathbf{3 c}$, intermolecular alkyl transfer is very unlikely because a single product is formed in which only one alkyl group is transferred. If the transfer were intermolecular, a mixture of products where either the $\mathrm{N}^{1}$ methyl or the $\mathrm{N}^{2}$-methyl were transferred would have been expected, as the two methyl groups of $\mathbf{3 c}$ should have comparable reactivity toward $\mathrm{S}_{\mathrm{N}} 2$ displacement given the similar diphenylamine leaving groups. Products from outright loss of alkyl groups from dealkylation by KDA were not isolated. 


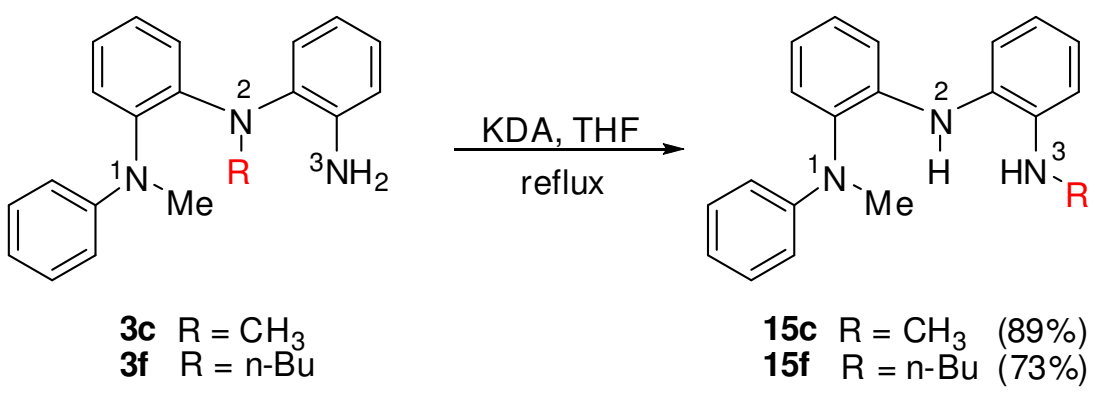

Scheme 5: Alkyl transfer without benzyne formation

\section{CONCLUSIONS}

It was originally hoped that a benzyne intermediate would provide an efficient route to the targeted 1,4,7-triazacyclononatriene 2a. Models suggested that overlap of the $\mathrm{N}^{3}$ anilide with the in-plane benzyne orbital would be ideal for the final cyclization step of the linear synthesis. However, when NMR spectra from the benzyne cyclization reactions commencing with halo derivatives 3 were compared with those of the purified N,N'-dimethyl-1,4,7-triazacyclononatriene orthocyclophane molecule isolated from Buchwald-Hartwig N-arylation conditions, there was no trace of the 9-membered cyclophane detected in the crude mixtures by ${ }^{1} \mathrm{H}$ NMR, whereas the apparent alkylshifted phenazine derivatives $\mathbf{5 a} / \mathbf{b}$ were formed very efficiently, in $78-98 \%$ depending on the halogen and alkyl group present. This conversion is dependent upon two factors: the halogen present and the alkyl group employed as the substituent on the internal nitrogen. The evidence provided by these studies suggests the possibility of a neutral $\mathrm{N}^{2}$ aniline nucleophile attacking the proximal carbon of the aryne affording a zwitterionic intermediate $(\mathbf{1 4} \mathbf{a} / \mathbf{b})$ followed by an alkyl shift from $\mathrm{N}^{2}$ to $\mathrm{N}^{3}$ to afford a phenazine derivative. We envisioned that this may occur via a rare 5-endo-tet pathway, although a 
classic Smiles rearrangement may be more likely since theoretical studies do not support a frontside attack, which would be required in a genuine 5-endo-tet process. Specifically, Hase $^{31}$ has performed an ab initio $\left(\mathrm{HF} / 3-21+\mathrm{G}^{*}\right)$ trajectory study of the $\mathrm{S}_{\mathrm{N}} 2$ reaction of $\mathrm{Cl}^{-}+\mathrm{CH}_{3} \mathrm{Cl}$ at a reagent relative translational energy of $100 \mathrm{kcal} / \mathrm{mol}$ and observed the expected backside attack but no frontside attack, and suggested that extensive electrophile vibrational energy would be required for frontside attack. Furthermore, reported 5-endo-tet processes ${ }^{26}$ are ambiguously categorized since they involve 3membered ring (generally epoxide) openings under acidic conditions with significant carbocation character, and hence are more appropriately categorized as (allowed) 5-exotrig reactions. Indeed, Baldwin noted that three-membered ring openings lie between tetrahedral and trigonal systems. ${ }^{25}$ It may be noted that some confusion arises upon categorization of the cyclizations of a 3,4-epoxy butan-1-ol system to form a tetrahydrofuran, which is an "endo" cyclization (per Baldwin) but could be considered either an allowed 5-exo-tet or a disfavored 6-endo-tet (counting the oxygen atom of the epoxide as part of the larger ring). As noted, a genuine 5-endo-tet pathway would involve attack by a nucleophile at the same face as the leaving group, in opposition to the classic $\mathrm{S}_{\mathrm{N}} 2$ trajectory of $180^{\circ}$, thus it is unlikely that the intramolecular alkyl transfer occurs as depicted in Scheme 3, and more likely is the result of a Smiles rearrangement, although the intermediacy of the zwitterionic intermediate $(\mathbf{1 4 a / 1 4 b})$ remains an intriguing possibility. Labeling experiments would be required to definitely differentiate between these possibilities. Further experiments are underway to study this unusual and theoretically interesting alkyl transfer in more detail. 


\section{EXPERIMENTAL SECTION}

\section{General Experimental Methods}

All solvents were distilled prior to use. All reagents were used without further purification unless otherwise noted. All Pd-catalyzed and $\mathrm{Cu}$-catalyzed reactions were conducted under an inert atmosphere of argon, and all other reactions were conducted under a nitrogen atmosphere. Silica gel 60A, 40-75 $\mu \mathrm{m}(200 \times 400$ mesh $)$ was used for column chromatography. Aluminum-backed silica gel $200 \mu \mathrm{m}$ plates were used for TLC. ${ }^{1} \mathrm{H}$ NMR spectra were obtained utilizing a $300 \mathrm{MHz}$ spectrometer with trimethylsilane (TMS) as the internal standard. ${ }^{13} \mathrm{C}$ NMR spectra were obtained using a $75 \mathrm{MHz}$ spectrometer. A 300 watt microwave reactor with pressure and temperature sensors was used for all microwave (MW) reactions. Infrared (IR) spectra were determined as a solution in $\mathrm{CHCl}_{3}$. HRMS spectra were measured on a TOF instrument by electrospray ionization (ESI). Single crystal X-ray diffraction data were collected on a chargecoupled-device (CCD) diffractometer with a liquid nitrogen vapor cooling device. Data were collected at $100 \mathrm{~K}$ with graphite monochromatized $\operatorname{MoK} \alpha \mathrm{X}$-ray radiation $(\lambda=$ $0.71073 \AA$ ). Collected and reduced data were corrected for absorption using multi-scan methods. The structure was solved by direct methods and refined by full matrix least squares against $F^{2}$ with all reflections. Non hydrogen atoms were refined anisotropically. $\mathrm{C}-\mathrm{H}$ hydrogen atom positions were idealized. Additional details of the structure determinations for the tosylate and hydrochloride salts of $\mathbf{5 a}$ can be found in the supporting information and the supplementary cif files.

\section{$N$-Methyl-2-(10-methylphenazin-5(10H)-yl)aniline (2a)}


Similar to the procedure employed by Panagopoulos et al. ${ }^{9}$ but under optimized thermal conditions, a $125 \mathrm{~mL}$ pressure flask was charged with XPhos (426 mg, $0.89 \mathrm{mmol})$ and $\mathrm{Pd}(\mathrm{dba})_{2}(255 \mathrm{mg}, 0.443 \mathrm{mmol})$ and a solution of compound $\mathbf{3 a}(712 \mathrm{mg}, 2.11 \mathrm{mmol})$ in $42 \mathrm{~mL}$ anhydrous 1,4-dioxane was added. The resulting solution was stirred at room temperature for 15 minutes as argon was passed over the top of the solution. Then cesium carbonate $(1.38 \mathrm{~g}, 4.23 \mathrm{mmol})$ was added as a solid and the resulting suspension purged with argon for 30 minutes. The flask was then sealed and heated in a $140^{\circ} \mathrm{C}$ oil bath for 16 hours. The reaction mixture was cooled to room temperature and filtered through a pad of Celite and the filter cake washed with $1: 1$ methanol/ $\mathrm{CH}_{2} \mathrm{Cl}_{2}$. The filtrate was concentrated to dryness leaving a brown solid which was dissolved in ethyl acetate and the solution passed through a plug of silica gel eluting with $2: 1$ pet ether $/ \mathrm{CH}_{2} \mathrm{Cl}_{2}$. The filtrate was concentrated to dryness leaving a tan powder that was dissolved in $\mathrm{CH}_{2} \mathrm{Cl}_{2}$. The $\mathrm{CH}_{2} \mathrm{Cl}_{2}$ solution was purified by flash chromatography eluting with a gradient from $10 \% \mathrm{CH}_{2} \mathrm{Cl}_{2} /$ pet ether to $33 \% \mathrm{CH}_{2} \mathrm{Cl}_{2}$ /pet ether to give $\mathbf{2 a}(375 \mathrm{mg}, 59 \%$ yield) as a tan powder, mp $228-230^{\circ} \mathrm{C}$.

\section{$N^{1}$-(2-Aminophenyl)-- $N^{2}$-(2-fluorophenyl)- $N^{1}, N^{2}$-dimethylbenzene-1,2-diamine (3b)}

$\mathrm{CuCl}$ (137 mg, $1.38 \mathrm{mmol}$ ) was added to a stirring solution of the nitroaryl derivative $\mathbf{1 0 b}$ (164 mg, $0.46 \mathrm{mmol})$ in dry $\mathrm{MeOH}(5 \mathrm{~mL})$ at rt. $\mathrm{KBH}_{4}(248 \mathrm{mg}, 4.60 \mathrm{mmol})$ was then added in portions. ${ }^{13}$ The reaction effervesced and a black precipitate formed upon each addition. Once all the $\mathrm{KBH}_{4}$ was added, the reaction continued to stir at rt until the 
solution became clear in color (2-4 h). The reaction was quenched with $\mathrm{H}_{2} \mathrm{O}$ and extracted with 3 x 10 mL 90/10 EA/MC. The organic layers were combined and dried over $\mathrm{Na}_{2} \mathrm{SO}_{4}$. The solvent was removed under vacuum to give the aniline $\mathbf{3 b}$ as a light brown oil (144 g, 98\% yield). ${ }^{1} \mathrm{H}$ NMR (300 MHz, $\left.\mathrm{CDCl}_{3}\right) \delta 7.12(2 \mathrm{H}, \mathrm{m}), 7.00(2 \mathrm{H}$, m), $6.92(3 \mathrm{H}, \mathrm{m}), 6.78(2 \mathrm{H}, \mathrm{m}), 6.65(2 \mathrm{H}, \mathrm{m}), 6.56(1 \mathrm{H}, \mathrm{dd}, \mathrm{J}=9.2,1.5 \mathrm{~Hz}), 3.17$ ( $2 \mathrm{H}$, bs), $3.08(3 \mathrm{H}, \mathrm{s}), 2.97(3 \mathrm{H}, \mathrm{s}) ;{ }^{13} \mathrm{C}$ NMR $\left(75 \mathrm{MHz}, \mathrm{CDCl}_{3}\right) \delta 154.1(\mathrm{~d}, \mathrm{~J}=270 \mathrm{~Hz})$, $145.2,141.7,140.8,137.4,137.1,127.0,125.6,124.9,124.0,123.5,122.6,120.1,119.9$, 119.3, 118.7, 116.4, 116.1, 39.8, 38.4; IR $\left(\mathrm{CDCl}_{3}\right) 3435\left(\mathrm{NH}_{2}\right), 3346\left(\mathrm{NH}_{2}\right), 1612(\mathrm{C}=\mathrm{C})$, $1501\left(\mathrm{NO}_{2}\right) \mathrm{cm}^{-1}$; HRMS MH $\mathrm{H}^{+}$calcd for $\mathrm{C}_{20} \mathrm{H}_{21} \mathrm{~N}_{3} \mathrm{~F} 322.1719$ found 322.1728 .

\section{$N^{1}$-(2-Aminophenyl)- $N^{1}, N^{2}$-dimethyl- $N^{2}$-phenylbenzene-1,2-diamine (3c)}

$\mathrm{CuCl}(0.297 \mathrm{~g}, 3 \mathrm{mmol})$ was added to a stirring solution of the nor-halo dimethyl derivative 10c $(0.212 \mathrm{~g}, 1.00 \mathrm{mmol})$ in a 1:1 mixture of dry $\mathrm{MeOH}$ and $\mathrm{MC}(20 \mathrm{~mL})$ at $\mathrm{rt}$. $\mathrm{KBH}_{4}(0.540 \mathrm{~g}, 8.0 \mathrm{mmol})$ was then added in portions. ${ }^{21}$ The reaction effervesced and a black ppt formed upon each addition. Once all the $\mathrm{KBH}_{4}$ was added, the reaction continued to stir at rt until the solution became clear in color and TLC showed consumption of 10c (2-4 h). The reaction was quenched with $\mathrm{H}_{2} \mathrm{O}$ and extracted with $3 \mathrm{x}$ $10 \mathrm{~mL}$ 90/10 EA/MC. The organic layers were combined and dried over $\mathrm{Na}_{2} \mathrm{SO}_{4}$. The solvent was removed under vacuum to give the N,N'-dimethyl diphenylamine derivative

3c as a light brown oil $(0.163 \mathrm{~g}, 96 \%$ yield $) .{ }^{1} \mathrm{H} \mathrm{NMR}\left(500 \mathrm{MHz}, \mathrm{CDCl}_{3}\right) \delta 7.27(1 \mathrm{H}$, td, $\mathrm{J}=6.3,2.3 \mathrm{~Hz}), 7.21(1 \mathrm{H}, \mathrm{d}, \mathrm{J}=4.8 \mathrm{~Hz}), 7.10(2 \mathrm{H}, \mathrm{td}, \mathrm{J}=7.0,1.0 \mathrm{~Hz}), 7.05-7.04(2 \mathrm{H}$, m), $6.87(1 \mathrm{H}, \mathrm{td}, \mathrm{J}=7.5,1.0 \mathrm{~Hz}), 6.66(1 \mathrm{H}, \mathrm{td}, \mathrm{J}=7.5,1.2 \mathrm{~Hz}), 6.61-6.58(3 \mathrm{H}, \mathrm{m}), 6.31$ 
$(2 \mathrm{H}, \mathrm{dd}, \mathrm{J}=8.5,1.0 \mathrm{~Hz}), 2.99(2 \mathrm{H}, \mathrm{br} \mathrm{s}), 2.97(3 \mathrm{H}, \mathrm{s}), 2.50(3 \mathrm{H}, \mathrm{s}) .{ }^{13} \mathrm{C} \mathrm{NMR}(125 \mathrm{MHz}$, $\left.\mathrm{CDCl}_{3}\right) \delta 147.8,147.3,142.8,138.7,138.3,129.9,128.6,126.8,125.3,123.9,122.6$, 118.8, 118.6, 116.2, 116.1, 112.3, 38.4, 37.9. HRMS MH+ Calc for $\mathrm{C}_{20} \mathrm{H}_{22} \mathrm{~N}_{3} 304.1808$, found 304.1808 .

\section{$N^{1}$-(2-Aminophenyl)- $N^{1}$-butyl- $N^{2}$-(2-chlorophenyl)- $N^{2}$-methylbenzene-1,2-diamine} (3d)

Following the general procedure of Sanz, ${ }^{21} \mathrm{CuCl}(0.060 \mathrm{~g}, 0.060 \mathrm{mmol})$ was added to a stirring solution of compound 10d $(0.079 \mathrm{~g}, 0.2 \mathrm{mmol})$ in $\mathrm{MeOH}(2.0 \mathrm{~mL})$ at $\mathrm{rt}$, then $\mathrm{KBH}_{4}(0.108 \mathrm{~g}, 2.0 \mathrm{mmol})$ was added in portions. The reaction stirred at rt until the solution became clear (2-4 h). The reaction was then quenched with $\mathrm{H}_{2} \mathrm{O}$ and extracted 3 $\times 15 \mathrm{~mL}$ 90/10 EA/DCM. The organic layers were combined and dried over $\mathrm{Na}_{2} \mathrm{SO}_{4}$ and the solvent was removed to give the desired aniline $\mathbf{3 d}$ as a brown oil $(0.063 \mathrm{~g}, 82 \%) .{ }^{1} \mathrm{H}$ NMR $\left(300 \mathrm{MHz}, \mathrm{CDCl}_{3}\right) \delta 7.29(1 \mathrm{H}, \mathrm{dd}, \mathrm{J}=7.8,1.5 \mathrm{~Hz}), 7.15-7.00(4 \mathrm{H}, \mathrm{m}), 6.95-6.84$ $(5 \mathrm{H}, \mathrm{m}), 6.73-6.62(2 \mathrm{H}, \mathrm{m}), 3.46(5 \mathrm{H}, \mathrm{m}), 3.20(3 \mathrm{H}, \mathrm{s}), 1.42-1.32(2 \mathrm{H}, \mathrm{m}), 1.25-1.16(2 \mathrm{H}$, m), $0.82(3 \mathrm{H}, \mathrm{t}, \mathrm{J}=7.2 \mathrm{~Hz}) ;{ }^{13} \mathrm{C} \mathrm{NMR}\left(75 \mathrm{MHz}, \mathrm{CDCl}_{3}\right) \delta 147.2,143.3,143.2,142.4$, $135.8,131.2,127.4,127.3,125.3,124.8,124.5,123.7,123.0,118.4,116.4,50.6,40.3$, 30.2, 20.5, 14.1; IR $\left(\mathrm{CDCl}_{3}\right) 3436\left(\mathrm{NH}_{2}\right), 3375\left(\mathrm{NH}_{2}\right), 2956(\mathrm{C}-\mathrm{H}), 2929(\mathrm{C}-\mathrm{H}), 2869$ (C$\mathrm{H}), 1491(\mathrm{C}=\mathrm{C}) \mathrm{cm}^{-1}$; HRMS MH${ }^{+}$calcd for $\mathrm{C}_{23} \mathrm{H}_{27} \mathrm{~N}_{3} \mathrm{Cl}$ 380.1888, found 380.1892.

\section{$N^{1}$-(2-Aminophenyl)- $N^{1}$-butyl- $N^{2}$-(2-fluorophenyl)- $N^{2}$-methylbenzene-1,2-diamine} $(3 e)$ 
$\mathrm{CuCl}$ (47 mg, $0.48 \mathrm{mmol}$ ) was added to a stirring solution of nitroaryl derivative 10e (63 $\mathrm{mg}, 0.17 \mathrm{mmol})$ in dry $\mathrm{MeOH}(2 \mathrm{~mL})$ at $\mathrm{rt} . \mathrm{KBH}_{4}(86 \mathrm{mg}, 1.6 \mathrm{mmol})$ was then added in portions. ${ }^{21}$ The reaction effervesced and a black ppt formed upon each addition. Once all the $\mathrm{KBH}_{4}$ was added, the reaction continued to stir at rt until the solution became clear in color (2-4 h). The reaction was quenched with $\mathrm{H}_{2} \mathrm{O}$ and extracted with 3 x $10 \mathrm{~mL}$ 90/10 EA/MC. The organic layers were combined and dried over $\mathrm{Na}_{2} \mathrm{SO}_{4}$. The solvent was removed under vacuum to give the aniline derivative $\mathbf{3 e}$ as a light brown oil $(60 \mathrm{mg}$, $100 \%$ yield). ${ }^{1} \mathrm{H}$ NMR $\left(300 \mathrm{MHz}, \mathrm{CDCl}_{3}\right) \delta$ 7.18-6.99 $(5 \mathrm{H}, \mathrm{m}), 6.95-6.86(2 \mathrm{H}, \mathrm{m}), 6.78-$ $6.71(2 \mathrm{H}, \mathrm{m}), 6.66-6.60(2 \mathrm{H}, \mathrm{m}), 6.50(1 \mathrm{H}, \mathrm{ddd}, \mathrm{J}=9.6,8.2,1.8 \mathrm{~Hz}), 3.38(2 \mathrm{H}, \mathrm{t}, \mathrm{J}=$ 7.8 Hz), 3.20 ( 2H, bs), $2.90(3 \mathrm{H}, \mathrm{s}), 1.51-1.41(2 \mathrm{H}, \mathrm{m}), 1.32-1.20(2 \mathrm{H}, \mathrm{m}), 0.86(3 \mathrm{H}, \mathrm{t}$, $\mathrm{J}=7.3 \mathrm{~Hz}) ;{ }^{1} \mathrm{H} \mathrm{NMR}\left(\mathrm{CDCl}_{3}, 125 \mathrm{MHz}\right) \delta 154.2(\mathrm{~d}, \mathrm{~J}=274 \mathrm{~Hz}), 145.9,142.6,142.1$, 137.3, 128.0, 125.8, 125.1, 124.7, 124.2, 121.4, 121.3, 121.0, 119.8, 119.8, 119.4, 118.7, 116.5, 116.3, 50.9, 40.4, 30.0, 20.6, 14.2 ppm; HRMS $\mathrm{MH}^{+}$calcd for $\mathrm{C}_{23} \mathrm{H}_{27} \mathrm{~N}_{3} \mathrm{~F}$ 364.2184, found 364.2175.

\section{$N^{1}$-(2-Aminophenyl)- $N^{1}$-butyl- $N^{2}$-methyl- $N^{2}$-phenylbenzene-1,2-diamine (3f)}

Compound $10 f(633 \mathrm{mg}, 1.69 \mathrm{mmol})$ was dissolved in $17 \mathrm{~mL}$ dry methanol and the solution stirred at RT. According to the general method of Sanz, ${ }^{21}$ to that solution was added $\mathrm{CuCl}$ (508 $\mathrm{mg}, 5.13 \mathrm{mmol}$ ) in one portion and stirring was continued for $10 \mathrm{~min}$ before $\mathrm{KBH}_{4}(738 \mathrm{mg}, 13.7 \mathrm{mmol})$ was added portion-wise maintaining the reaction temperature below $30^{\circ} \mathrm{C}$. The reaction mixture was stirred at ambient temperature under 
nitrogen atmosphere for $2.5 \mathrm{~h}$. The reaction was then quenched via the addition of water and then was extracted $3 \times$ with ethyl acetate. The organic extracts were combined, dried over $\mathrm{MgSO}_{4}$, filtered and the filtrate concentrated to dryness leaving a brown gum that was purified by flash chromatography eluting with an eluent comprised of 3\% ether, 5\% methylene chloride and $92 \%$ petroleum ether to give triaryl derivative $\mathbf{3 f}$ (202 mg, 25\%

yield, 2 steps $)$ as a brown oil. ${ }^{1} \mathrm{H}$ NMR $\left(500 \mathrm{MHz}, \mathrm{CDCl}_{3}\right) \delta$ 7.29-7.26 $(1 \mathrm{H}, \mathrm{m}), 7.13(1 \mathrm{H}$, d, J=8.0 Hz), $7.08(1 \mathrm{H}, \mathrm{t}, \mathrm{J}=11.0 \mathrm{~Hz}), 7.05-7.01(2 \mathrm{H}, \mathrm{m}), 6.86-6.83(1 \mathrm{H}, \mathrm{m}), 6.66(1 \mathrm{H}, \mathrm{t}$, $\mathrm{J}=7.0 \mathrm{~Hz}), 6.60-6.54(2 \mathrm{H}, \mathrm{m}), 6.32(1 \mathrm{H}, \mathrm{s}), 6.30(1 \mathrm{H}, \mathrm{s}), 3.27(2 \mathrm{H}, \mathrm{t}, \mathrm{J}=8.0 \mathrm{~Hz}), 2.99(2 \mathrm{H}$, bs), $2.46(3 \mathrm{H}, \mathrm{s}), 1.61-1.55(4 \mathrm{H}, \mathrm{m}), 1.30(2 \mathrm{H}, \mathrm{q}, \mathrm{J}=7.5 \mathrm{~Hz}), 0.99(3 \mathrm{H}, \mathrm{t}, \mathrm{J}=7.5 \mathrm{~Hz}) .{ }^{13} \mathrm{C}$ NMR (125 MHz, $\left.\mathrm{CDCl}_{3}\right) \delta 147.3,146.2,143.1,139.8,138.3,130.3,128.5,126.5,125.0$, 124.7, 122.7, 119.7, 118.5, 116.2, 116.0, 112.4, 50.6, 37.9, 29.8, 20.4,14.0. HRMS MH ${ }^{+}$ Calc for $\mathrm{C}_{23} \mathrm{H}_{28} \mathrm{~N}_{3} 346.2278$, found 346.2279 .

\section{$N$-Methyl-2-(10-methylphenazin-5(10H)-yl)aniline (5a)}

In an oven-dried round-bottom flask, $\mathrm{KH}(0.543 \mathrm{~g}, 4.06 \mathrm{mmol})$ was washed with dry pet ether ( $3 \times 5 \mathrm{~mL}$ ) under $\mathrm{N}_{2}$ at $\mathrm{rt}$, and $1 \mathrm{~mL}$ of THF was added to the $\mathrm{KH}$ and stirred at $\mathrm{rt}$ for $5 \mathrm{~min}$. Diisopropylamine $(0.15 \mathrm{~mL}, 1.0 \mathrm{mmol})$ was then added to the $\mathrm{KH}$ and the mixture stirred at rt for $5 \mathrm{~min}$. Compound 3a $(0.098 \mathrm{~g}, 0.29 \mathrm{mmol})$ in THF ( $5 \mathrm{~mL})$ was added dropwise by syringe to the KDA in THF ( $1 \mathrm{~mL})$. The mixture was heated to reflux for 1-2 hr until TLC showed complete consumption of 3a. The reaction mixture was quenched with $15 \mathrm{~mL}$ of $\mathrm{H}_{2} \mathrm{O}$ and extracted $3 \times 20 \mathrm{~mL} \mathrm{Et}_{2} \mathrm{O}$. The organic layers were combined and dried over $\mathrm{MgSO}_{4}$ and the solvent was removed in vacuo to yield 
phenazine 5a as a colorless solid (80 mg, 92\%): $\mathrm{mp} 202-204{ }^{\circ} \mathrm{C} ;{ }^{1} \mathrm{H}$ NMR $(300 \mathrm{MHz}$, $\left.\mathrm{CDCl}_{3}\right) \delta 7.33(1 \mathrm{H}, \mathrm{ddd}, \mathrm{J}=9.2,7.8,1.5 \mathrm{~Hz}), 7.16(1 \mathrm{H}, \mathrm{dd}, \mathrm{J}=8.1,1.5 \mathrm{~Hz}), 6.82(2 \mathrm{H}, \mathrm{t}$, $\mathrm{J}=15.7,7.8 \mathrm{~Hz}), 6.63(2 \mathrm{H}, \mathrm{ddd}, \mathrm{J}=9.1,7.7,1.4 \mathrm{~Hz}), 6.41(2 \mathrm{H}, \mathrm{ddd}, \mathrm{J}=8.7,7.8,1.2$ $\mathrm{Hz}), \delta 6.34(2 \mathrm{H}, \mathrm{dd}, \mathrm{J}=7.7,1.1 \mathrm{~Hz}), \delta 5.82(2 \mathrm{H}, \mathrm{dd}, \mathrm{J}=7.8,1.2 \mathrm{~Hz}), \delta 4.45(1 \mathrm{H}, \mathrm{bs})$, $3.01(3 \mathrm{H}, \mathrm{s}), 2.79(3 \mathrm{H}, \mathrm{bs}) ;{ }^{13} \mathrm{C} \mathrm{NMR}\left(75 \mathrm{MHz}, \mathrm{CDCl}_{3}\right) \delta 146.9,136.9,131.1,129.6$, 129.2, 125.5, 121.7, 120.7, 117.5, 111.8, 111.2, 110.9, 30.2, 29.7; $\mathrm{HRMS} \mathrm{M}^{+}$calcd for $\mathrm{C}_{20} \mathrm{H}_{20} \mathrm{~N}_{3} 301.1573$, found 301.1562 . The desired product was then dissolved in 2-3 mL of $\mathrm{Et}_{2} \mathrm{O}$ and 1 equivalent of p-toluenesulfonic acid was added to form the tosylate salt as clear crystals suitable for X-ray crystallography. Similarly, addition of $\mathrm{HCl} /$ ether to $\mathbf{5 a}$ in $\mathrm{Et}_{2} \mathrm{O}$ afforded the hydrochloride salt as clear crystals suitable for X-ray crystallography.

\section{$N$-Butyl-2-(10-methylphenazin-5(10H)-yl)aniline (5b)}

In a round bottom flask, $2 \mathrm{~mL}$ of THF and DIPA $(0.11 \mathrm{~mL}, 0.80 \mathrm{mmol})$ were added to $\mathrm{KH}(0.300 \mathrm{~g}, 2.24 \mathrm{mmol})$ at $\mathrm{rt}$. The mixture was stirred for $10 \mathrm{~min}$ and aniline $\mathbf{3 e}(58 \mathrm{mg}$, $0.16 \mathrm{mmol}$ ) in $3 \mathrm{~mL}$ of THF was added dropwise via syringe. The reaction mixture was heated to reflux for $2 \mathrm{~h}$. The reaction mixture was cooled to rt and quenched with $\mathrm{H}_{2} \mathrm{O}$. The product was extracted with $3 \times 20 \mathrm{~mL}$ of $90 / 10 \mathrm{EA} / \mathrm{MC}$. The organic layers were combined and dried over $\mathrm{Na}_{2} \mathrm{SO}_{4}$, the solvent was removed under reduced pressure to give the phenazine derivative $\mathbf{5 b}$ as a green oil $\left(0.048 \mathrm{~g}, 87 \%\right.$ yield). ${ }^{1} \mathrm{H}$ NMR $(500 \mathrm{MHz}$, $\left.\mathrm{CDCl}_{3}\right) \delta 7.3(1 \mathrm{H}, \mathrm{ddd}, \mathrm{J}=8.5,7.3,2.3), 7.16,(1 \mathrm{H}, \mathrm{dd}, \mathrm{J}=7.7,1.4), 6.83-6.75(2 \mathrm{H}, \mathrm{m})$, $6.62(2 \mathrm{H}, \mathrm{t}, \mathrm{J}=7.7), 6.41(1 \mathrm{H}, \mathrm{t}, 7.7), 6.34(1 \mathrm{H}, \mathrm{d}, \mathrm{J}=7.8), 5.81(2 \mathrm{H}, \mathrm{dd}, \mathrm{J}=7.8,1.2)$, $4.37(1 \mathrm{H}, \mathrm{bs}), 3.12(2 \mathrm{H}, \mathrm{t}, \mathrm{J}=7.1), 3.02(3 \mathrm{H}, \mathrm{s}), 1.55-1.43(2 \mathrm{H}, \mathrm{m}), 1.36-1.21(2 \mathrm{H}, \mathrm{m})$, 
$0.85(3 \mathrm{H}, \mathrm{t}, \mathrm{J}=7.3) ;{ }^{13} \mathrm{C} \mathrm{NMR}\left(125 \mathrm{MHz}, \mathrm{CDCl}_{3}\right) \delta 137.2,131.5,129.7,121.9,121.1$, 117.7, 112.2, 112.0, 111.1, 43.3, 31.6, 29.9, 20.3, 14.0 (all aromatic carbons peaks are broadened due to hindered rotation except for 129.7, while the aliphatic carbon resonances are sharp); IR $\left(\mathrm{CDCl}_{3}\right) 3415(\mathrm{NH}), 2965(\mathrm{C}-\mathrm{H}), 2962(\mathrm{C}-\mathrm{H}), 2870(\mathrm{C}-\mathrm{H})$, $1607(\mathrm{C}=\mathrm{C}), 1508(\mathrm{C}=\mathrm{C}), 1482(\mathrm{C}=\mathrm{C}) \mathrm{cm}^{-1}$; HRMS M${ }^{+}$calcd for $\mathrm{C}_{23} \mathrm{H}_{26} \mathrm{~N}_{3} 343.2043$, found 343.2046.

\section{(2'-Fluorophenyl)-(2-nitrophenyl)-amine (6b)}

(2'-Fluorophenyl)-(2-nitrophenyl)-amine $\mathbf{6 b}$ was synthesized according to the general procedures outlined by Tietze $e t a l .{ }^{23}$ A pressure tube was charged with o-nitroaniline (0.690 g, $5.00 \mathrm{mmol})$, o-fluoroiodobenzene (0.70 mL, $6 \mathrm{mmol}), \operatorname{Pd}(\mathrm{dba})_{2}(0.144 \mathrm{~g}, 5 \%)$, BINAP $(0.233 \mathrm{~g}, 7.5 \%), \mathrm{Cs}_{2} \mathrm{CO}_{3}(3.26 \mathrm{~g}, 10 \mathrm{mmol})$ and toluene $(10 \mathrm{~mL})$. The mixture was purged with argon for $10 \mathrm{~min}$ at $\mathrm{rt}$ and the pressure tube was sealed. The reaction was placed in an oil bath. The temperature was brought to $120^{\circ} \mathrm{C}$ and the reaction stirred for $24 \mathrm{~h}$. TLC showed complete consumption of o-nitroaniline and the reaction mixture was filtered through a pad of $\mathrm{SiO}_{2}$ using 10/90 DCM/EA as the eluent. The solvent was removed under reduced pressure and product was purified by column chromatography using $1 / 99 \mathrm{Et}_{2} \mathrm{O} / \mathrm{PE}$ as the eluent to afford the final product $\mathbf{6} \mathbf{b}$ as orange crystals $(0.915$ g, $78 \%$ yield): $\mathrm{mp} 79-80{ }^{\circ} \mathrm{C} ;{ }^{1} \mathrm{H}$ NMR $\left(300 \mathrm{MHz}, \mathrm{CDCl}_{3}\right) \delta 9.31(1 \mathrm{H}, \mathrm{br} \mathrm{s}), 8.24(1 \mathrm{H}, \mathrm{dd}$, $\mathrm{J}=8.7,1.5 \mathrm{~Hz}), 7.44-7.37(2 \mathrm{H}, \mathrm{m}), 7.24-7.18(3 \mathrm{H}, \mathrm{m}), 7.08(1 \mathrm{H}, \mathrm{dt}, \mathrm{J}=2.9,1.5,1.4 \mathrm{~Hz})$,

$6.83(1 \mathrm{H}, \mathrm{ddd}, \mathrm{J}=7.2,7.0,1.2 \mathrm{~Hz}) .{ }^{13} \mathrm{C} \mathrm{NMR}\left(75 \mathrm{MHz}, \mathrm{CDCl}_{3}\right) \delta 156.6(\mathrm{~d}, \mathrm{~J}=248 \mathrm{~Hz})$, 142.2, 139.4, 135.7, 130.1, 126.8, 125.9, 124.7, 118.1, 116.8, 116.7, 116.0; IR $\left(\mathrm{CDCl}_{3}\right)$ 
$3345(\mathrm{NH}), 1609(\mathrm{C}=\mathrm{C}), 1577(\mathrm{C}=\mathrm{C}), 1509\left(\mathrm{NO}_{2}\right) \mathrm{cm}^{-1}$; HRMS $(\mathrm{M}+\mathrm{H})+$ calcd for $\mathrm{C}_{12} \mathrm{H}_{10} \mathrm{~N}_{2} \mathrm{O}_{2} \mathrm{~F}$ 233.0721, found 233.0727.

\section{2-Nitro- $N$-phenylaniline (6c)}

2-Nitro-N-phenylaniline $\mathbf{6 c}$ was synthesized according to the general procedures outlined by Tietze et al. ${ }^{23}$ A pressure tube was charged with o-nitroaniline $(1.38 \mathrm{~g}, 10 \mathrm{mmol})$, bromobenzene (1.2 mL, $10 \mathrm{mmol}), \operatorname{Pd}(\mathrm{dba})_{2}(0.288 \mathrm{~g}, 5 \%)$, BINAP (0.466 g, 7.5\%), $\mathrm{Cs}_{2} \mathrm{CO}_{3}(6.52 \mathrm{~g}, 20 \mathrm{mmol})$ and toluene $(20 \mathrm{~mL})$. The mixture was purged with argon for 10 min at $\mathrm{rt}$ and the pressure tube was sealed. The reaction was placed in an oil bath. The temperature was brought to $120^{\circ} \mathrm{C}$ and the reaction stirred for $48 \mathrm{~h}$. TLC showed complete consumption of o-nitroaniline and the reaction mixture was filtered through a pad of silica gel using 5/5/90 EA/MC/PE as the eluent. The filtrate was dried over $\mathrm{Na}_{2} \mathrm{SO}_{4}$ and the solvent removed under reduced pressure to give the desired 2-nitro-Nphenylaniline $\mathbf{6 c}$ as an orange solid without further purification $\left(2.08 \mathrm{~g}, 98 \%\right.$ yield). ${ }^{1} \mathrm{H}$ NMR $\left(300 \mathrm{MHz}, \mathrm{CDCl}_{3}\right) \delta 9.48(1 \mathrm{H}, \mathrm{bs}), 8.19(1 \mathrm{H}, \mathrm{dd}, \mathrm{J}=8.7,1.8 \mathrm{~Hz}), 7.43(1 \mathrm{H}, \mathrm{d}, \mathrm{J}=1.8$ $\mathrm{Hz}), 7.41-7.32(2 \mathrm{H}, \mathrm{m}), 7.28-7.23(4 \mathrm{H}, \mathrm{m}), 6.76(1 \mathrm{H}, \mathrm{dd}, \mathrm{J}=1.8,1.2 \mathrm{~Hz}) .{ }^{13} \mathrm{C}$ NMR $(75$ $\left.\mathrm{MHz}, \mathrm{CDCl}_{3}\right) \delta 142.9,138.6,135.5,133.0,129.6,126.5,125.5,124.2,117.4,115.9$.

\section{2-Fluoro- $N$-methyl- $N$-(2-nitrophenyl)aniline (7b)}

To a solution of aniline $\mathbf{6 b}(0.122 \mathrm{~g}, 0.525 \mathrm{mmol})$ in acetone $(2 \mathrm{~mL})$ at $\mathrm{rt}$ was added freshly crushed $\mathrm{KOH}(0.130 \mathrm{~g}, 2.31 \mathrm{mmol})$. The reaction was heated to reflux and 
$\mathrm{Me}_{2} \mathrm{SO}_{4}(0.23 \mathrm{~mL}, 2.42 \mathrm{mmol})$ was added dropwise via syringe. The mixture was allowed to reflux for $1 \mathrm{~h}$. The reaction was cooled to rt and $1 \mathrm{~mL}$ of $10 \mathrm{M} \mathrm{NaOH}$ was added to the solution. After $1 \mathrm{~h}$ the mixture was quenched with $2 \mathrm{~mL} \mathrm{H}_{2} \mathrm{O}$ and extracted with $3 \times 10 \mathrm{~mL}$ of 90/10 EA/MC. The organic layers were combined and dried over $\mathrm{MgSO}_{4}$. The solvent was removed under reduced pressure and the mixture was placed in an $80^{\circ} \mathrm{C}$ oil bath under vacuum to remove excess $\mathrm{Me}_{2} \mathrm{SO}_{4}$ providing fluoro nitrobenzene derivative $7 \mathbf{b}$ as a brown oil $(0.122 \mathrm{~g}, 95 \%$ yield $) .{ }^{1} \mathrm{H}$ NMR $\left(300 \mathrm{MHz}, \mathrm{CDCl}_{3}\right) \delta 7.73$ $(1 \mathrm{H}, \mathrm{dd}, \mathrm{J}=7.8,1.7 \mathrm{~Hz}), 7.5(1 \mathrm{H}, \mathrm{ddd}, \mathrm{J}=8.2,7.4,1.7 \mathrm{~Hz}), 7.24(1 \mathrm{H}, \mathrm{dd}, \mathrm{J}=8.4,1.2$ $\mathrm{Hz}), 7.09-6.94(5 \mathrm{H}, \mathrm{m}), 3.33(3 \mathrm{H}, \mathrm{s}) ;{ }^{13} \mathrm{C} \mathrm{NMR}\left(75 \mathrm{MHz}, \mathrm{CDCl}_{3}\right) \delta 155.6(\mathrm{~d}, \mathrm{~J}=255$ Hz), 142.5, 138.9, 136.9, 126.9, 125.7, 125.4, 122.6, 120.8, 119.3, 117.2, 116.5, 41.1; IR $\left(\mathrm{CDCl}_{3}\right) 1522\left(\mathrm{NO}_{2}\right), 1501\left(\mathrm{NO}_{2}\right) \mathrm{cm}^{-1} ; \operatorname{HRMS}(\mathrm{M}+\mathrm{H})+$ calcd for $\mathrm{C}_{13} \mathrm{H}_{11} \mathrm{~N}_{2} \mathrm{O}_{2} \mathrm{~F}$ 247.0877, found 247.0871.

\section{$N$-Methyl-2-nitro- $N$-phenylaniline (7c)}

To a solution of aniline $6 \mathrm{c}(0.182 \mathrm{~g}, 1.0 \mathrm{mmol})$ in DMF $(5 \mathrm{~mL})$ at $\mathrm{rt}$ was added freshly crushed $\mathrm{KOH}(0.252 \mathrm{~g}, 4.5 \mathrm{mmol})$. After $10 \mathrm{~min}$, MeI (0.20 mL, $3 \mathrm{mmol})$ was added to the stirring mixture dropwise via syringe. Stirring was continued at $\mathrm{rt}$ until TLC showed consumption of the aniline starting material. The reaction was then quenched with $25 \mathrm{~mL}$ deionized $\mathrm{H}_{2} \mathrm{O}$ and extracted with $3 \times 30 \mathrm{~mL}$ of EA. The organic layers were combined and dried over $\mathrm{MgSO}_{4}$. The solvent was removed under reduced pressure and no further purification was needed to obtain the nor-halo $\mathrm{N}$-methyl derivative $\mathbf{7} \mathbf{c}^{24}$ as a brown oil. (0.194 g, 100\% yield). ${ }^{1} \mathrm{H}$ NMR (300 MHz, $\left.\mathrm{CDCl}_{3}\right) \delta 7.83(1 \mathrm{H}, \mathrm{dd}, \mathrm{J}=8.1,1.5 \mathrm{~Hz}), 7.57$ 
$(1 \mathrm{H}, \mathrm{dt}, \mathrm{J}=8.6,1.8 \mathrm{~Hz}), 7.35(1 \mathrm{H}, \mathrm{dd}, \mathrm{J}=8.1,1.5 \mathrm{~Hz}), 7.27(2 \mathrm{H}, \mathrm{dt}, \mathrm{J}=15.4,1.5 \mathrm{~Hz}), 7.21$

$(2 \mathrm{H}, \mathrm{dt}, \mathrm{J}=8.1,1.5 \mathrm{~Hz}), 6.83(1 \mathrm{H}, \mathrm{dt}, \mathrm{J}=7.2,1.2 \mathrm{~Hz}), 6.72(1 \mathrm{H}, \mathrm{dt}, \mathrm{J}=7.2,1.2 \mathrm{~Hz}), 3.31$

$(3 \mathrm{H}, \mathrm{s}) .{ }^{13} \mathrm{C}$ NMR $\left(75 \mathrm{MHz}, \mathrm{CDCl}_{3}\right) \delta 147.8,146.3,142.2,133.8,129.2,129.1,125.6$, $125.0,119.9,115.6,40.2$.

\section{$N^{1}$-(2-Fluorophenyl)- $N^{1}$-methylbenzene-1,2-diamine (8b)}

$\mathrm{CuCl}(0.150 \mathrm{~g}, 1.50 \mathrm{mmol})$ was added to a stirring solution of fluoro nitrobenzene derivative $7 \mathbf{b}(0.122 \mathrm{~g}, 0.5 \mathrm{mmol})$ in dry $\mathrm{MeOH}(5.0 \mathrm{~mL})$ at $\mathrm{rt} . \mathrm{KBH}_{4}(0.270 \mathrm{~g}, 5.0$ mmol) was then added in portions. ${ }^{21}$ The reaction effervesced and a black precipitate formed upon each addition. Once all the $\mathrm{KBH}_{4}$ was added, the reaction continued to stir at rt until the solution became clear in color (2-4 h). The reaction was quenched with $\mathrm{H}_{2} \mathrm{O}$ and extracted with 3 x $10 \mathrm{~mL}$ 90/10 EA/MC. The organic layers were combined and dried over $\mathrm{Na}_{2} \mathrm{SO}_{4}$. The solvent was removed under vacuum to give the desired fluoro aniline $\mathbf{8 b}$ as a light brown oil $\left(0.096 \mathrm{~g}, 89 \%\right.$ yield). ${ }^{1} \mathrm{H} \mathrm{NMR}\left(300 \mathrm{MHz}, \mathrm{CDCl}_{3}\right) \delta 7.06-$ $6.85(6 \mathrm{H}, \mathrm{m}), 6.76(1 \mathrm{H}, \mathrm{dd}, \mathrm{J}=7.8,1.2 \mathrm{~Hz}), 6.70(1 \mathrm{H}, \mathrm{ddd}, \mathrm{J}=8.8,7.7,1.4 \mathrm{~Hz}), 3.91(2 \mathrm{H}$, bs), $3.15(3 \mathrm{H}, \mathrm{s}) ;{ }^{13} \mathrm{C}$ NMR (75 MHz, $\left.\mathrm{CDCl}_{3}\right) \delta 154.9(\mathrm{~d}, \mathrm{~J}=240 \mathrm{~Hz}), 142.1,138.6$, 136.8, 126.1, 124.5 (d, J = 37 Hz), 121.7, 119.6, 118.8, 116.4, 116.1, 115.8, 34.0; IR $\left(\mathrm{CDCl}_{3}\right) 3452\left(\mathrm{NH}_{2}\right), 3351\left(\mathrm{NH}_{2}\right), 1608(\mathrm{C}=\mathrm{C}), 1500(\mathrm{C}=\mathrm{C}) \mathrm{cm}^{-1}$; HRMS MH ${ }^{+}$calcd for $\mathrm{C}_{13} \mathrm{H}_{14} \mathrm{~N}_{2} \mathrm{~F} 217.1136$, found 217.1133.

$N^{1}$-Methyl- $N^{1}$-phenylbenzene-1,2-diamine (8c) 
$\mathrm{CuCl}(0.297 \mathrm{~g}, 3 \mathrm{mmol})$ was added to a stirring solution of the nor-halo $\mathrm{N}$-methyl derivative 7c $(0.208 \mathrm{~g}, 1.00 \mathrm{mmol})$ in dry $\mathrm{MeOH}(10 \mathrm{~mL})$ at rt. $\mathrm{KBH}_{4}(0.540 \mathrm{~g}, 8.0$ mmol) was then added in portions. ${ }^{21}$ The reaction effervesced and a black precipitate formed upon each addition. Once all the $\mathrm{KBH}_{4}$ was added, stirring was continued at $\mathrm{rt}$ until the solution became clear in color and TLC showed consumption of 7c (2-4 h). The reaction was quenched with $\mathrm{H}_{2} \mathrm{O}$ and extracted with 3 x $10 \mathrm{~mL}$ 90/10 EA/MC. The organic layers were combined and dried over $\mathrm{Na}_{2} \mathrm{SO}_{4}$. The solvent was removed under vacuum to give the $\mathrm{N}$-methyl diphenylamine derivative $\mathbf{8 c ^ { 2 4 }}$ as a light brown oil $(0.163 \mathrm{~g}$, 96\% yield). ${ }^{1} \mathrm{H}$ NMR (300 MHz, $\left.\mathrm{CDCl}_{3}\right) \delta 7.19(2 \mathrm{H}, \mathrm{dt}, \mathrm{J}=5.4,1.8 \mathrm{~Hz}), 7.07(1 \mathrm{H}, \mathrm{dt}$, $\mathrm{J}=7.8,1.5 \mathrm{~Hz}), 7.03) 1 \mathrm{H}, \mathrm{dd}, \mathrm{J}=7.8,1.5 \mathrm{~Hz}), 6.80-6.72(3 \mathrm{H}, \mathrm{m}), 6.66(1 \mathrm{H}, \mathrm{s}), 6.63(1 \mathrm{H}$, s), $3.77(2 \mathrm{H}, \mathrm{bs}), 3.19(3 \mathrm{H}, \mathrm{s})$.

\section{$N^{1}$-(2-Fluorophenyl)- $N^{1}$-methyl- $N^{2}$-(2-nitrophenyl)benzene-1,2-diamine (9b)}

The fluoroaniline derivative $\mathbf{8 b}(0.096 \mathrm{~g}, 0.44 \mathrm{mmol})$, o-iodonitrobenzene $(0.132 \mathrm{~g}, 0.53$ mmol), Pd(dba) $2(0.013 \mathrm{~g}, 5 \% \mathrm{~mol}), \mathrm{BINAP}(0.021 \mathrm{~g}, 7.5 \% \mathrm{~mol}), \mathrm{Cs}_{2} \mathrm{CO}_{3}(0.215 \mathrm{~g}, 0.66$ $\mathrm{mmol}$ ) and $2 \mathrm{~mL}$ of toluene were placed in a pressure tube. The mixture was purged with argon at $\mathrm{rt}$ for $15 \mathrm{~min}$. The pressure tube was then sealed and placed in a pre-heated oil bath at $130^{\circ} \mathrm{C}$ for $24 \mathrm{~h}$. When TLC showed consumption of $\mathbf{8 b}$, the reaction mixture was filtered through a pad of $\mathrm{SiO}_{2}$ eluting with 90/10 EA/MC. The solvent was removed under reduced pressure and the resulting product was purified by column chromatography eluting with $1 / 99 \mathrm{Et}_{2} \mathrm{O}$ /pet ether to afford the $\mathrm{N}, \mathrm{N}$ '-diaryl 
phenylenediamine derivative $9 \mathbf{b}$ as a red oil $\left(0.082 \mathrm{~g}, 55 \%\right.$ yield). ${ }^{1} \mathrm{H}$ NMR (300 MHz, $\left.\mathrm{CDCl}_{3}\right) \delta 9.12(1 \mathrm{H}, \mathrm{bs}), 8.05(1 \mathrm{H}, \mathrm{dd}, \mathrm{J}=8.5,1.7 \mathrm{~Hz}), 7.34-7.05(6 \mathrm{H}, \mathrm{m}), 6.86-6.83(4 \mathrm{H}$, m), $6.69(1 \mathrm{H}$, ddd, $\mathrm{J}=8.5,7.1,1.4 \mathrm{~Hz}), 3.21(3 \mathrm{H}, \mathrm{s}),{ }^{13} \mathrm{C} \mathrm{NMR}\left(75 \mathrm{MHz}, \mathrm{CDCl}_{3}\right) \delta 156.3$ $(\mathrm{d}, \mathrm{J}=240 \mathrm{~Hz}), 144.4,142.3,137.8,135.1,133.4,132.5,126.4,125.7,124.2,123.7$, 123.5, 122.7, 122.4, 117.1, 116.4, 116.1, 115.8, 40.6; IR ( $\left.\mathrm{CDCl}_{3}\right) 3343(\mathrm{NH}), 1615$ $(\mathrm{C}=\mathrm{C}), 1593(\mathrm{C}=\mathrm{C}), 1573(\mathrm{C}=\mathrm{C}), 1501\left(\mathrm{NO}_{2}\right) \mathrm{cm}^{-1}$; HRMS MH${ }^{+}$calcd for $\mathrm{C}_{19} \mathrm{H}_{17} \mathrm{~N}_{3} \mathrm{O}_{2} \mathrm{~F}$ 338.1299 , found 338.1306 .

\section{$N^{1}$-Methyl- $N^{2}$-(2-nitrophenyl)- $N^{1}$-phenylbenzene-1,2-diamine (9c)}

Nor-halo aniline derivative $8 \mathrm{c}(0.163 \mathrm{~g}, 2.5 \mathrm{mmol})$, o-iodonitrobenzene $(0.249 \mathrm{~g}, 2.50$ mmol), Pd(dba) 2 (0.072 g, 5\% mol), BINAP (0.112 g, 7.5\% mol), $\mathrm{Cs}_{2} \mathrm{CO}_{3}(0.900 \mathrm{~g}, 2.75$ $\mathrm{mmol}$ ) and $5 \mathrm{~mL}$ of toluene were placed in a pressure tube. The mixture was purged with argon at $\mathrm{rt}$ for $15 \mathrm{~min}$. The pressure tube was then sealed and placed in a pre-heated oil bath at $120^{\circ} \mathrm{C}$ for $36 \mathrm{~h}$. When TLC showed consumption of $\mathbf{8 c}$, the reaction mixture was filtered through a pad of silica gel eluting with 90/10 EA/MC. The solvent was removed under reduced pressure and the resulting product was purified by column chromatography eluting with 10/90 EA/pet ether to afford the desired dimethyl derivative 9c as a yellow gum $(0.163 \mathrm{~g}, 70 \%$ yield $) .{ }^{1} \mathrm{H} \mathrm{NMR}\left(300 \mathrm{MHz}, \mathrm{CDCl}_{3}\right) \delta 9.24(1 \mathrm{H}, \mathrm{s})$, $8.08(1 \mathrm{H}, \mathrm{dd}, \mathrm{J}=9.9,1.8 \mathrm{~Hz}), 7.47-7.43(1 \mathrm{H}, \mathrm{m}), 7.34-7.20(5 \mathrm{H}, \mathrm{m}), 7.11(2 \mathrm{H}, \mathrm{dt}, \mathrm{J}=6.4$, $1.0 \mathrm{~Hz}), 6.74(2 \mathrm{H}, \mathrm{ddd}, \mathrm{J}=7.5,7.9,1.2 \mathrm{~Hz}), 6.65(1 \mathrm{H}, \mathrm{d}, \mathrm{J}=1.0 \mathrm{~Hz}), 6.62(1 \mathrm{H}, \mathrm{d}, \mathrm{J}=1.0$ $\mathrm{Hz}), 3.23(3 \mathrm{H}, \mathrm{s}) .{ }^{13} \mathrm{C} \mathrm{NMR}(75 \mathrm{MHz}, \mathrm{CDCl} 3) \delta 148.6,142.1,141.8,135.6,135.12$, 
133.9, 129.0, 127.8, 126.6, 126.0, 125.9, 123.7, 119.1, 117.7, 116.1, 115.1, 39.6. HRMS $\mathrm{MH}^{+}$Calc for $\mathrm{C}_{19} \mathrm{H}_{18} \mathrm{~N}_{3} \mathrm{O}_{2}$ 320.1394, found 320.1394.

$N^{1}$-(2-Fluorophenyl)-- $N^{1}, N^{2}$-dimethyl- $N^{2}$-(2-nitrophenyl)benzene-1,2-diamine (10b)

A solution of fluoro nitroaryl derivative $9 \mathbf{b}(0.082 \mathrm{~g}, 0.24 \mathrm{mmol})$ in $2 \mathrm{~mL}$ of DMF was added to KH (0.100 g, $0.72 \mathrm{mmol}$, freshly washed with pet ether). Upon addition, the solution changed color from orange to deep purple. The mixture was stirred at $\mathrm{rt}$ for 10 min, then methyl iodide $(1.0 \mathrm{~mL}, 1.2 \mathrm{mmol})$ was added dropwise via syringe. Stirring was continued until the solution became bright yellow in color $(2 \mathrm{~h})$. The reaction was then quenched with $\mathrm{H}_{2} \mathrm{O}$ and extracted with $3 \times 10 \mathrm{~mL} 90 / 10 \mathrm{EA} / \mathrm{CH}_{2} \mathrm{Cl}_{2}$. The organic layers were combined and washed with $3 \times 20 \mathrm{~mL} \mathrm{H}_{2} \mathrm{O}$, then brine. The organic layer was dried over $\mathrm{Na}_{2} \mathrm{SO}_{4}$, and the solvent was removed under reduced pressure to give the desired $\mathrm{N}^{1}, \mathrm{~N}^{2}$-dimethyl derivative $\mathbf{1 0 b}$ as a yellow solid (0.082 g, 97\% yield). ${ }^{1} \mathrm{H} \mathrm{NMR}$ $\left(500 \mathrm{MHz}, \mathrm{CDCl}_{3}\right) \delta 7.62(1 \mathrm{H}, \mathrm{dd}, \mathrm{J}=8.2,1.7 \mathrm{~Hz}), 7.34(1 \mathrm{H}, \mathrm{ddd}, \mathrm{J}=8.8,7.4,1.9 \mathrm{~Hz})$,

7.1-6.75 (10H, m), $3.22(3 \mathrm{H}, \mathrm{s}), 3.14$ ( $3 \mathrm{H}, \mathrm{s}) ;{ }^{13} \mathrm{C} \mathrm{NMR}(125 \mathrm{MHz}, \mathrm{CDCl} 3) \delta 155.1$ (d, J $=148 \mathrm{~Hz}), 143.0,143.8,140.9,137.6,132.9,132.6(\mathrm{~d}, \mathrm{~J}=25 \mathrm{~Hz}), 125.9,125.8,125.6$, 125.1, 125.0, $124.4(\mathrm{~d}, \mathrm{~J}=2 \mathrm{~Hz}), 122.1(\mathrm{~d}, \mathrm{~J}=5 \mathrm{~Hz}), 121.7,121.5(\mathrm{~d}, \mathrm{~J}=2 \mathrm{~Hz}), 120.0$, $116.5(\mathrm{~d}, \mathrm{~J}=12 \mathrm{~Hz}), 40.1,39.2$; IR $\left(\mathrm{CDCl}_{3}\right) 1606(\mathrm{C}=\mathrm{C}), 1591(\mathrm{C}=\mathrm{C}), 1568(\mathrm{C}=\mathrm{C}), 1522$ $\left(\mathrm{NO}_{2}\right), 1500\left(\mathrm{NO}_{2}\right) \mathrm{cm}^{-1}$; HRMS $(\mathrm{M}+\mathrm{H})+$ calcd for $\mathrm{C}_{20} \mathrm{H}_{19} \mathrm{~N}_{3} \mathrm{O}_{2} \mathrm{~F} 352.1456$, found 352.1463.

$N^{1}, N^{2}$-Dimethyl- $N^{1}$-(2-nitrophenyl)- $N^{2}$-phenylbenzene-1,2-diamine (10c) 
To a solution of aniline 9c $(0.163 \mathrm{~g}, 2.0 \mathrm{mmol})$ in DMF $(10 \mathrm{~mL})$ at $\mathrm{rt}$ was added freshly crushed $\mathrm{KOH}(0.504 \mathrm{~g}, 9 \mathrm{mmol})$. After $10 \mathrm{~min}$, MeI $(0.40 \mathrm{~mL}, 6 \mathrm{mmol})$ was added to the stirring mixture dropwise via syringe. Stirring was continued at rt until TLC showed consumption of the aniline starting material. The reaction was then quenched with $25 \mathrm{~mL}$ deionized water and extracted with 3 x $30 \mathrm{~mL}$ of EA. The organic layers were combined and dried over $\mathrm{MgSO}_{4}$. The solvent was removed under reduced pressure to provide the nor-halo N,N'-dimethyl derivative 10c as a brown oil. (0.170 g, 100\% yield). ${ }^{1} \mathrm{H}$ NMR $\left(300 \mathrm{MHz}, \mathrm{CDCl}_{3}\right) \delta 7.59(1 \mathrm{H}, \mathrm{dd}, \mathrm{J}=8.2,1.6 \mathrm{~Hz}), 7.29-7.15(3 \mathrm{H}, \mathrm{m}), 7.11-7.04(4 \mathrm{H}, \mathrm{m})$, $6.92(1 \mathrm{H}, \mathrm{dt}, \mathrm{J}=7.2,1.2 \mathrm{~Hz}), 6.76(1 \mathrm{H}, \mathrm{dd}, \mathrm{J}=8.2,1.2 \mathrm{~Hz}), 6.72(1 \mathrm{H}, \mathrm{dt}, \mathrm{J}=13.5,1.2 \mathrm{~Hz})$, $6.34(1 \mathrm{H}, \mathrm{d}, \mathrm{J}=3.2 \mathrm{~Hz}), 6.31(1 \mathrm{H}, \mathrm{d}, \mathrm{J}=1.9 \mathrm{~Hz}), 3.27(3 \mathrm{H}, \mathrm{s}), 2.82(3 \mathrm{H}, \mathrm{s}) .{ }^{13} \mathrm{C}$ NMR $(75$ $\left.\mathrm{MHz}_{\mathrm{CDCl}}\right) \delta 147.8,144.1,143.5,142.9,140.1,132.8,129.0,128.4,126.5,125.3$, 124.7, 124.4, 123.6, 121.5, 117.5, 113.9, 41.2, 38.1. HRMS $\mathrm{MH}^{+}$calc for $\mathrm{C}_{20} \mathrm{H}_{20} \mathrm{~N}_{3} \mathrm{O}_{2}$ 334.1550, found 334.1547.

\section{$N^{1}$-Butyl- $N^{2}$-(2-chlorophenyl)- $N^{2}$-methyl- $N^{1}$-(2-nitrophenyl)benzene-1,2-diamine (10d)}

A solution of chloro $\mathrm{N}^{1}$-methyl aniline derivative $9 \mathbf{a}^{9}(0.100 \mathrm{~g}, 0.28 \mathrm{mmol})$ in $2 \mathrm{~mL}$ of DMF was added to $\mathrm{KH}(0.112 \mathrm{~g}, 0.830 \mathrm{mmol})$. Upon addition, the solution went from orange to deep purple. The mixture was stirred at $\mathrm{rt}$ for $10 \mathrm{~min}$. $n$-Butyl bromide $(0.30$ $\mathrm{mL}, 2.8 \mathrm{mmol}$ ) was added dropwise via syringe. The reaction was warmed to $80^{\circ} \mathrm{C}$ and stirred until the solution returned to an orange color $(3 \mathrm{~h})$. The reaction was then 
quenched with $\mathrm{H}_{2} \mathrm{O}$ and extracted with $3 \times 15 \mathrm{~mL}$ EA. The organic layers were combined and washed with $3 \times 25 \mathrm{~mL} \mathrm{H}_{2} \mathrm{O}$, brine, then again with $\mathrm{H}_{2} \mathrm{O}$ to remove excess DMF. The organic layer was then dried over $\mathrm{MgSO}_{4}$, and the solvent was removed under reduced pressure. The crude product was purified by column chromatography using a gradient of EA/pet ether as the eluent to give the desired product $10 \mathbf{d}$ as a red oil $(0.065$ g, 56\%). ${ }^{1} \mathrm{H}$ NMR $\left(300 \mathrm{MHz}, \mathrm{CDCl}_{3}\right) \delta 7.57(1 \mathrm{H}, \mathrm{dd}, \mathrm{J}=8.0,1.7 \mathrm{~Hz}), 7.40(1 \mathrm{H}, \mathrm{ddd}, \mathrm{J}=$ 8.7, 7.2, 1.6 Hz), $7.24(1 \mathrm{H}, \mathrm{dd}, \mathrm{J}=15.4,1.4 \mathrm{~Hz}), 7.21(1 \mathrm{H}, \mathrm{dd}, \mathrm{J}=14.8,1.7 \mathrm{~Hz}), 7.06($ $1 \mathrm{H}, \mathrm{dd}, \mathrm{J}=8.1,1.5 \mathrm{~Hz}), 7.02-6.87(6 \mathrm{H}, \mathrm{m}), 6.76(1 \mathrm{H}, \mathrm{dd}, \mathrm{J}=8.2,1.7 \mathrm{~Hz}), 3.77(2 \mathrm{H}, \mathrm{t}, \mathrm{J}=$ $8.1 \mathrm{~Hz}), 3.31(3 \mathrm{H}, \mathrm{s}), 1.6(2 \mathrm{H}, \mathrm{m}), 1.29(2 \mathrm{H}, \mathrm{m}), 0.90(3 \mathrm{H}, \mathrm{t}, \mathrm{J}=7.4,7.1 \mathrm{~Hz}) ;{ }^{13} \mathrm{C}$ NMR $\left(75 \mathrm{MHz}, \mathrm{CDCl}_{3}\right) \delta 146.7,132.8,132.3,131.0,130.1,128.4,128.3,127.8,127.5,126.3$, $125.9,125.8,124.1,124.0,123.7,120.7,120.6,119.1,49.8,38.6,29.0,20.1,14.0$ IR $\left(\mathrm{CDCl}_{3}\right) 2958(\mathrm{C}-\mathrm{H}), 2929(\mathrm{C}-\mathrm{H}), 2871(\mathrm{C}-\mathrm{H}), 2817(\mathrm{C}-\mathrm{H}), 1524\left(\mathrm{NO}_{2}\right) \mathrm{cm}^{-1}$; HRMS $\mathrm{MH}^{+}$calcd for $\mathrm{C}_{23} \mathrm{H}_{25} \mathrm{~N}_{3} \mathrm{O}_{2} \mathrm{Cl}$ 410.1630, found 410.1640 .

\section{$N^{1}$-Butyl- $N^{2}$-(2-fluorophenyl)- $N^{2}$-methyl- $N^{1}$-(2-nitrophenyl)benzene-1,2-diamine} (10e)

A solution of the fluoro nitroaryl derivative $9 \mathbf{b}(0.102 \mathrm{~g}, 0.300 \mathrm{mmol})$ in $2 \mathrm{~mL}$ of DMF was added to $\mathrm{KH}(0.121 \mathrm{~g}, 0.910 \mathrm{mmol})$. Upon addition, the solution went from orange to deep purple. The mixture was stirred at $\mathrm{rt}$ for $10 \mathrm{~min} . n$-Butyl bromide $(0.32 \mathrm{~mL}, 3.0$ mmol) was added dropwise via syringe. The reaction was heated to $80^{\circ} \mathrm{C}$ and stirred until the solution returned to an orange color $3 \mathrm{~h}$. The reaction was then quenched with $\mathrm{H}_{2} \mathrm{O}$ and extracted with $3 \times 15 \mathrm{~mL}$ DCM. The organic layers were combined and washed with 
$3 \times 25 \mathrm{~mL} \mathrm{H}_{2} \mathrm{O}$, with brine and then with $\mathrm{H}_{2} \mathrm{O}$ again to remove excess DMF. The organic layer was then dried over $\mathrm{MgSO}_{4}$, and the solvent was removed under reduced pressure. The crude product was purified by column chromatography using a gradient of EA/PE as the eluent to produce the $\mathrm{N}^{1}$-methyl- $\mathrm{N}^{2}$-butyl derivative $10 \mathrm{e}$ as a red oil $(0.063 \mathrm{~g}, 53 \%)$. ${ }^{1} \mathrm{H}$ NMR $\left(300 \mathrm{MHz}, \mathrm{CDCl}_{3}\right) \delta 7.57(1 \mathrm{H}, \mathrm{dd}, \mathrm{J}=8.1,1.5 \mathrm{~Hz}), 7.34(1 \mathrm{H}, \mathrm{ddd}, \mathrm{J}=8.7,7.3$, $1.7 \mathrm{~Hz}), 7.11-6.77(9 \mathrm{H}, \mathrm{m}), 3.59(2 \mathrm{H}, \mathrm{t}, \mathrm{J}=15.9,8.0 \mathrm{~Hz}), 3.06(3 \mathrm{H}, \mathrm{s}), 1.65-1.54(2 \mathrm{H}$, m), $1.30(2 \mathrm{H}, \mathrm{s}, \mathrm{J}=7.3 \mathrm{~Hz}), 0.88(3 \mathrm{H}, \mathrm{t}, \mathrm{J}=7.3 \mathrm{~Hz}) ;{ }^{13} \mathrm{C} \mathrm{NMR}\left(75 \mathrm{MHz}, \mathrm{CDCl}_{3}\right) \delta 154.4$ $(\mathrm{d}, \mathrm{J}=255 \mathrm{~Hz}), 141.8,141.0,137.5,132.6,132.3,132.0,130.1,129.3(\mathrm{~d}, \mathrm{~J}=30 \mathrm{~Hz})$, 128.3, 127.8, 125.8, 125.6, 125.1, 124.1, 122.6, 121.3, 120.8, 120.3, 116.3 (d, J = $22 \mathrm{~Hz})$, 52.5, 39.2, 29.7, 20.3, 13.9; HRMS MH+ calcd for $\mathrm{C}_{23} \mathrm{H}_{25} \mathrm{~N}_{3} \mathrm{O}_{2} \mathrm{~F} 394.1925$, found 394.1939.

\section{$N^{1}$-Butyl- $N^{2}$-methyl- $N^{1}$-(2-nitrophenyl)- $N^{2}$-phenylbenzene-1,2-diamine (10f)}

Nitro triaryl compound $9 \mathrm{c}(735 \mathrm{mg}, 2.30 \mathrm{mmol})$ was placed in a round bottom flask and $12 \mathrm{~mL}$ anhydrous DMF was added. To that solution was added powdered $\mathrm{KOH}$ (593 mg, $10.6 \mathrm{mmol})$ and the reaction mixture stirred $10 \mathrm{~min}$ at RT. Then, $n$-butyl bromide $(3.21 \mathrm{~g}$, $23.4 \mathrm{mmol}$ ) was added neat and the reaction mixture was heated in an $80^{\circ} \mathrm{C}$ oil bath for $3 \mathrm{~h}$. The reaction mixture was then cooled to $\mathrm{RT}$ and diluted with $20 \mathrm{~mL}$ water and extracted $3 \times$ with diethyl ether. The organic extracts were combined, dried over $\mathrm{MgSO}_{4}$, filtered and the filtrate concentrated to dryness to give the $N$-butyl derivative $10 f$ as a brown oil that was carried on directly without further purification. 


\section{$N^{1}$-Methyl- $N^{2}$-(2-(methylamino)phenyl)- $N^{1}$-phenylbenzene-1,2-diamine (15c)}

A round bottom flask was charged with $30 \% \mathrm{KH}(187 \mathrm{mg}, 1.4 \mathrm{mmol})$ and the solid was washed under nitrogen atmosphere with $3 \times 5 \mathrm{~mL}$ portions of petroleum ether. The solid was then suspended in $1 \mathrm{~mL}$ anhydrous THF and stirred at RT while diisopropylamine $(50.0 \mu \mathrm{L}, 0.356 \mathrm{mmol})$ was added. Stirring at ambient temperature was continued for 10 min before $\mathrm{N}, \mathrm{N}^{\prime}$-dimethyl triaryl derivative $3 \mathrm{c}(30 \mathrm{mg}, 0.10 \mathrm{mmol})$ was added as a solution in $1 \mathrm{ml}$ THF. The reaction mixture was then heated and maintained at reflux for 2 $\mathrm{h}$ and then cooled to RT. The reaction mixture was diluted with water and extracted $2 \times$ with ethyl acetate. The organic extracts were combined, dried over $\mathrm{MgSO}_{4}$, filtered and the filtrate concentrated to dryness. The residue was dissolved in petroleum ether and purified by passing the solution through silica gel eluting with petroleum ether and then with $2 \%$ dichloromethane, $10 \%$ ether, $88 \%$ petroleum ether. The purified material was concentrated to dryness to give the product $15 \mathrm{c}$ as a clear gum $(26.8 \mathrm{mg}, 89 \%) .{ }^{1} \mathrm{H} \mathrm{NMR}$ $\left(500 \mathrm{MHz}, \mathrm{CDCl}_{3}\right) \delta 7.23(2 \mathrm{H}, \mathrm{t}, \mathrm{J}=7.5 \mathrm{~Hz}), 7.13-7.07(4 \mathrm{H}, \mathrm{m}), 6.80(2 \mathrm{H}, \mathrm{t}, \mathrm{J}=7.5 \mathrm{~Hz})$, $6.80(2 \mathrm{H}, \mathrm{t}, \mathrm{J}=7.5 \mathrm{~Hz}), 6.71(2 \mathrm{H}, \mathrm{t}, \mathrm{J}=4 \mathrm{~Hz}), 6.65(3 \mathrm{H}, \mathrm{t}, \mathrm{J}=3.0 \mathrm{~Hz}), 5.51(1 \mathrm{H}, \mathrm{s}), 4.06$ (1H, bs), $3.29(3 \mathrm{H}, \mathrm{s}), 2.76(3 \mathrm{H}, \mathrm{s}) .{ }^{13} \mathrm{C} \mathrm{NMR}\left(125 \mathrm{MHz}, \mathrm{CDCl}_{3}\right) \delta 149.3,146.0,143.3$, $135.0,129.4,128.0,127.6,127.4,126.8,125.9,119.5,118.4,117.0,114.1,114.0,110.5$, 39.4, 30.7. HRMS MH+ Calc for $\mathrm{C}_{20} \mathrm{H}_{22} \mathrm{~N}_{3}$ 304.1802, found 304.1802.

$N^{1}$-(2-(Butylamino)phenyl)- $N^{2}$-methyl- $N^{2}$-phenylbenzene-1,2-diamine (15f) 
A round bottom flask was charged with $30 \% \mathrm{KH}(374 \mathrm{mg}, 2.80 \mathrm{mmol})$ and the solid was washed with 3 portions of petroleum ether under nitrogen atmosphere. The solid was then suspended in $1 \mathrm{~mL}$ anhydrous THF and to that suspension was added distilled diisopropylamine $(100 \mu \mathrm{L}, 0.714 \mathrm{mmol})$. Stirring at ambient temperature was continued for $10 \mathrm{~min}$ before a solution of triaryl aniline $\mathbf{3 f}(69 \mathrm{mg}, 0.2 \mathrm{mmol})$ in $3 \mathrm{~mL}$ THF was added. The reaction mixture was then heated and maintained at reflux for $2 \mathrm{~h}$ before cooling to RT. The reaction mixture was diluted with water and extracted $2 \mathrm{X}$ ethyl acetate. The organic extracts were combined, dried over $\mathrm{MgSO}_{4}$, filtered and the filtrate concentrated to dryness. The residue was purified using flash chromatography eluting with $1 \%$ dichloromethane, $5 \%$ ether, $94 \%$ petroleum ether to give the product $\mathbf{1 5 f}$ as a pale yellow gum $(50.3 \mathrm{mg}, 73 \%) .{ }^{1} \mathrm{H} \mathrm{NMR}\left(500 \mathrm{MHz}, \mathrm{CDCl}_{3}\right) \delta 7.22(1 \mathrm{H}, \mathrm{d}, \mathrm{J}=1.0 \mathrm{~Hz})$, $7.21(1 \mathrm{H}, \mathrm{d}, \mathrm{J}=1.0 \mathrm{~Hz}), 7.12-7.07(4 \mathrm{H}, \mathrm{m}), 6.79(2 \mathrm{H}, \mathrm{dt}, \mathrm{J}=7.0,1.0 \mathrm{~Hz}), 6.72-6.64(5 \mathrm{H}$,

m), $5.54(1 \mathrm{H}, \mathrm{bs}), 3.99(1 \mathrm{H}, \mathrm{bs}), 3.30(3 \mathrm{H}, \mathrm{s}), 3.04(2 \mathrm{H}, \mathrm{t}, \mathrm{J}=7.0 \mathrm{~Hz}), 1.46(2 \mathrm{H}, \mathrm{q}, \mathrm{J}=7.5$ $\mathrm{Hz}), 1.28(2 \mathrm{H}, \mathrm{dq}, \mathrm{J}=7.5,1.0 \mathrm{~Hz}), 0.90(3 \mathrm{H}, \mathrm{t}, \mathrm{J}=7.5 \mathrm{~Hz}) .{ }^{13} \mathrm{C} \mathrm{NMR}\left(125 \mathrm{MHz}, \mathrm{CDCl}_{3}\right)$ $\delta 144.9,143.1,134.6,129.2,127.7,127.4,127.0,126.5,125.8,119.1,118.1,116.6$, 113.7, 113.7, 110.7, 43.4, 39.1, 31.6, 20.3, 13.9. HRMS $\mathrm{MH}^{+}$calc for $\mathrm{C}_{23} \mathrm{H}_{28} \mathrm{~N}_{3}$ 346.2278, found 346.2276.

\section{Acknowledgements}

NSF Grant No. DBI-0216630 is gratefully acknowledged for the Varian INOVA300 NMR obtained through the NSF Major Instrumentation Program. The X-ray diffractometer was funded by NSF Grant 0087210, Ohio Board of Regents Grant CAP491, and by Youngstown State University. 
Supporting Information Available: Includes copies of spectral data $\left({ }^{1} \mathrm{H} N M R,{ }^{13} \mathrm{C}\right.$ NMR, IR and HRMS), details of X-ray crystal structure determination, coordinates, and files for the tosylate and chloride salts of compound $\mathbf{5 a}$ (in CIF format). Ortep style representation for the chloride salt of compound 5a. This material is available free of charge via the Internet at http://pubs.acs.org.

\section{References}

(1) Collet, A. Tetrahedron 1987, 43, 5725-5759.

(2) Hardie, M. J. Chem. Soc. Rev. 2010, 39, 516-527.

(3) Hardie, M. J. In Cyclotriveratrylene and cryptophanes. Section Title: Physical Organic Chemistry; 2012; Vol. 3, pp 895-916.

(4) Brotin, T.; Dutasta, J. Chem. Rev. 2009, 109, 88-130.

(5) Lutz Jr., M. R.; French, D. C.; Rehage, P.; Becker, D. P. Tetrahedron Letters 2007, $48,6368-6371$.

(6) Lutz, M. R., Jr.; Zeller, M.; Becker, D. P. Tetrahedron Lett. 2008, 49, 5003-5005.

(7) Zeller, M.; Lutz, M. R., Jr.; Becker, D. P. Acta Crystallogr., Sect. B: Struct. Sci. 2009, B65, 223-229, S223/1-S223/10.

(8) Osner, Z. R.; Nyamjav, D.; Holz, R. C.; Becker, D. P. Nanotechnology 2011, 22, 275611/1-275611/6, S275611/1-S275611/3.

(9) Panagopoulos, A. M.; Zeller, M.; Becker, D. P. J. Org. Chem. 2010, 75, 7887-7892.

(10) Hartwig, J. F. Acc. Chem. Res. 1998, 31, 852-860. 
(11) Wolfe, J. P.; Wagaw, S.; Marcoux, J.; Buchwald, S. L. Acc. Chem. Res. 1998, 31, 805-818.

(12) Hartwig, J. F.; Kawatsura, M.; Hauck, S. I.; Shaughnessy, K. H.; Alcazar-Roman, L. M. J. Org. Chem. 1999, 64, 5575-5580.

(13) Muci, A. R.; Buchwald, S. L. Top. Curr. Chem. 2002, 219, 131-209.

(14) Bunnett, J. F.; Hrutfiord, B. F. J. Am. Chem. Soc. 1961, 83, 1691-1697.

(15) Huisgen, R.; Sauer, J. Angew. Chem. 1960, 72, 91-108.

(16) Sanz, R. Org. Prep. Proced. Int. 2008, 40, 215-291.

(17) Tadross, P. M.; Stoltz, B. M. Chem. Rev. 2012, 112, 3550-3577.

(18) Barluenga, J.; Fananas, F. J.; Sanz, R.; Fernandez, Y. Chem. --Eur. J. 2002, 8, 20342046.

(19) Kessar, S. V. In Comprehensive Organic Synthesis; Trost, B. M., Fleming, I., Eds.; 1991; Vol. 4, pp 483-515.

(20) DePuy, C. H.; Gronert, S.; Mullin, A.; Bierbaum, V. M. J. Am. Chem. Soc. 1990, $112,8650-8655$.

(21) Sanz, R.; Fernandez, Y.; Castroviejo, M. P.; Perez, A.; Fananas, F. J. J. Org. Chem. 2006, 71, 6291-6294.

(22) Wilshire, J. F. K. Aust. J. Chem. 1988, 41, 995-1001.

(23) Tietze, M.; Iglesias, A.; Merisor, E.; Conrad, J.; Klaiber, I.; Beifuss, U. Org. Lett. 2005, 7, 1549-1552.

(24) Moore, G. G. I.; Harrington, J. K.; Swingle, K. F. J. Med. Chem. 1975, 18, 386-391.

(25) Baldwin, J. E. J. Chem. Soc., Chem. Commun. 1976, 734-736.

(26) Prange, T.; Rodriguez, M. S.; Suarez, E. J. Org. Chem. 2003, 68, 4422-4431. 
(27) Truce, W. E.; Kreider, E. M.; Brand, W. W. Org. React. 1970, 18, 99-215.

(28) Rao, U. N.; Maguire, J.; Biehl, E. ARKIVOC (Gainesville, FL, U. S.) 2004, 88-100.

(29) Takagishi, S.; Schlosser, M. Synlett 1991, 119-121.

(30) Yoshida, H.; Sugiura, S.; Kunai, A. Org. Lett. 2002, 4, 2767-2769.

(31) Li, G.; Hase, W. L. J. Am. Chem. Soc. 1999, 121, 7124-7129. 
TOC Graphic
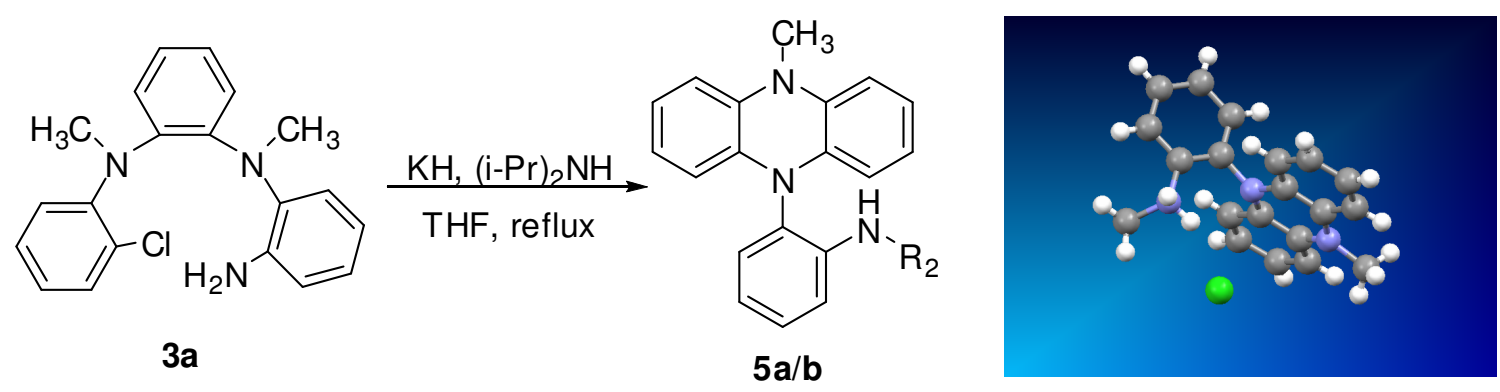